\title{
Molecular Markers for Risk Stratification in Adult Acute Myeloid Leukemia with Normal Cytogenetics
}

\author{
Ota Fuchs \\ Institute of Hematology and Blood Transfusion, Prague, \\ Center of Experimental Hematology, First Medical Faculty, Charles University, Prague, \\ Czech Republic
}

\section{Introduction}

Acute myeloid leukemia (AML) is a broad range of disorders that are all characterized by a block in the differentiation and by uncontrolled proliferation of hematopoietic progenitor cells. AML is the most frequent hematological malignancy in adults, with an annual incidence of three to four cases per 100000 individuals. Specific recurrent chromosomal abnormalities can be identified in approximately $55 \%$ of cases by cytogenetic analysis. These detected chromosomal aberrations are the most important tool to classify patients at their initial diagnosis and to divide them into favorable, intermediate and unfavorable subgroups. The age of the patient is also an important prognostic factor (Juliusson et al., 2009; Szotkowski et al., 2010). However, approximately $45 \%$ of adult patients with AML have normal karyotype (cytogenetically normal /CN/-AML patients) and are usually classified as an intermediate risk group (Mrozek et al., 2007; Smith et al., 2011). These patients have a 5 -year overall survival rate between $24 \%$ and $42 \%$, but clinical outcome may vary greatly.

The prognosis of AML with normal cytogenetics may be further subdivided based on genetic lesions. Even though a growing number of genetic lesions have been identified in CN-AML, about $25 \%$ CN-AML patients do not carry any of the currently known mutations. Therefore, many research groups conducted retrospective studies to find some candidate molecular markers that could identify good and poor risk AML patients with normal karyotype. In recent years, a number of gene mutations (NPM1 /nucleophosmin/, FLT3 /Fms-like tyrosine kinase 3/, MLL-PTD /mixed lineage leukemia-partial tandem duplications/, C/EBPa /CCAAT/enhancer-binding protein alpha/CEBPA/, WT1 /Wilms tumor 1/, DNMT3A /DNA methyltransferase 3A/, IDH1 and IDH2 /isocitrate dehydrogenase/, CBL /Casitas B-lineage lymphoma/and others), as well as deregulated expression of genes (BAALC / brain and acute leukemia cytoplasmic/, ERG /ETS-related gene/, MN1 /meningioma 1/, EVI1 / ecotropic virus integration 1/, AF1q /ALL1-fused gene chromosome 1q/, PRAME /preferentially expressed antigen in melanoma/, WT1) have been found and further molecular markers (gene expression profiles and microRNA expression signatures) are studied and incorporated into clinical practice (Baldus \& Bullinger, 2008; Bullinger \& Valk, 2005; Bullinger 2006; Kohlmann et al, 2010; Marcucci et 
al., 2009, 2011a,b; Motyckova \& Stone, 2010; Ramsingh et al., 2010; Schlenk et al., 2008; Wouters et al., 2009). It is necessary to improve current classification systems in order to reflect better the molecular heterogeneity of CN-AML (Döhner et al., 2010; Vardiman et al., 2009).

In addition, some of the genetic abnormalities have also been found to be useful for minimal residual disease (MRD) monitoring and as potential therapeutic targets in the development of new agents for AML therapy. The aim of monitoring of MRD is the identification of cases with a very high risk of relapse who then can be treated much earlier and more effectively (Jaeger \& Kainz, 2003; Schnittger et al., 2009; Shook et al., 2009).

Knowing the status of FLT-3 and other molecular markers (mutations and gene expression described above together with gene expression profiling) in CN-AML patients has not only prognostic significance but is important in the treatment based on these molecular markers. For example, patients with FLT3-ITD (an internal tandem duplication of the FLT3 receptor tyrosine kinase gene), who are not candidates for induction therapy and allogeneic stem cell transplantation may respond to an FLT3 inhibitor used in combination with chemotherapy or without chemotherapy. Deregulation of microRNA (miR) in CN-AML patients may act as complementary hit in the multisteps mechanism of leukemogenesis and has been not only used to identify subsets of CN-AML patients with diversified outcome but will certainly play a role in the future of treatment in new therapeutic strategies. Thus, miR expression profiling has diagnostic and prognostic significance.

\section{Methods for the detection of gene mutations and expression}

\subsection{Sample material}

After informed consent patient- or healthy individual-derived mononuclear cells were isolated from bone marrow (BM) or peripheral blood cells by a ficoll (for example FicollPaque PLUS, GE Healthcare Bio-Sciences AB, Uppsala, Sweden) density gradient centrifugation. Total RNA and genomic DNA were isolated. Yield and quality of the RNA were measured by spectrophotometric analysis. Each sample was assessed for the integrity of RNA by discrimination of $18 \mathrm{~S}$ and $28 \mathrm{~S}$ ribosomal RNA on $1 \%$ agarose gels using ethidium bromide for visualization. Complementary DNA was synthetised from total RNA using reverse transcriptase (for example SuperScript II reverse transcriptase (Invitrogen Corporation, Carlsbad, CA, USA).

\subsection{Detection of gene mutations}

Most mutation detection methods use PCR (polymerase chain reaction) to amplify the region of DNA of interest. Mutant DNA has a different secondary structure (conformation) compared with that of the normal DNA. Frequently, this difference in conformation results in altered gel electrophoresis mobility of the mutant DNA species. Single-strand conformation polymorphism (SSCP) method (Orita et al., 1989; Perry, 1999) based on this conformation change is a fast and efficient method for detecting many types of aberrations, including point mutations, insertions, deletions and rearrangements (Frayling, 2002; Kutach et al., 1999). SSCP has the sensitivity to identify single nucleotide changes in the DNA sequence. Thermally denaturated DNA is electrophoresed and mutation is detected as aberrantly migrating bands on the electrophoresis gel. Analyzed PCR products must be less than $300 \mathrm{bp}$ and preferably less than $200 \mathrm{bp}$ in size because the method is increasingly inefficient with increasing size of the PCR product. Another technique, related to SSCP is 
DNA heteroduplex analysis (Frayling, 2002). Both SSCP and heteroduplex analysis can be carried on fluorescent DNA analysers at a controlled temperature. The related techniques DGGE (denaturing gradient gel electrophoresis) and TGGE (thermal gradient gel electrophoresis) arevery efficient, but they require specially designed PCR primers of increased length (Frayling, 2002). Sequencing of the mutated PCR product is almost universally carried out using dideoxy terminator chemistry .

High resolution melting (HRM) analysis is rapidly becoming the most important initial screen procedure for potential mutations (Razga et al., 2009; Tan et al., 2008; Vaughn \& Elenitoba-Johnson, 2004; Wittwer, 2009). PCR amplification and subsequent HRM analysis are sequentially performed in the one tube. HRM is more simple than denaturing high performance liquid chromatography (DHPLC), which can be also used after PCR amplification for mutation detection (Bianchini et al., 2003; Kosaki et al., 2005; Roti et al., 2006). Real-time PCR machine with HRM capability, for example LightCycler 480 High Resolution Melting Master (Roche Diagnostics) has been successfully used for PCR amplification and HRM analysis. PCR reactions must be designed in the maner to avoid primer dimers and non-specific amplification. DNA has to be prepared in a uniform fashion to avoid variation in salt concentration with effect on the melting. HRM significantly reduces the quantity of samples that is necessary for sequencing with consequent reduction of cost and labour and enables rapid detection of mutations. The melting curves are normalized and temperature shifted to allow samples to be directly compared. Difference plots are generated by selecting a negative (nonmutated) control as the base-line and the fluorescence of all other samples is plotted relative to this negative control. Significant differences in fluorescence are indicative of mutations which must be detected by sequencing. Noordermer et al. (2010) used HRM curve analysis for rapid identification of IDH1 and IDH2 mutations in AML.

Currently, identification of mutations by PCR and direct nucleotide sequencing is used as the gold standard. The great progress was achieved in DNA sequencing technology in last ten years after the end of Human Genome Project (Mardis, 2011). The Roche/454, Life Technologies SOliD and Illumina instruments have been used to sequence the complete tumor and normal genomes in order to identify mutations that alter the protein-coding genes. Whole genome sequencing is now possible at a reasonable cost per tumor and normal genome of around \$30,000 and can be completed in about 8 days. A pilot study of high-throughput, sequence-based mutational profiling of primary AML cell genomes was done eight years ago (Ley et al., 2003). Whole genomic DNA sequencing of a cytogenetically normal FAB M1 AML patient was done three years ago and discovered ten genes with acquired mutations (Ley et al., 2008). Eight novel somatic mutations were described in genes not previously implicated in AML pathogenesis. Two well-known AML-associated mutations, including FLT3-ITD, which constitutively activates kinase signaling and a four base insertion in exon 12 of the NPM1 gene were also detected. Mardis et al. (2009) identified twelve somatic mutations within the coding sequences of genes and 52 somatic point mutations in conserved or regulatory portions of the AML genome. Two known mutations in NRAS and NPM1 and ten novel mutations were detected. One of these mutations (missense R132C mutation in IDH1 gene) is today included in many mutational screening of AML patients. The more efficient, faster and cheaper approach will be sequencing of coding regions (the cDNA transcriptome) but the abundance of transripts can vary and some mutations can be missed (Greif et al., 2011). The size of the transcriptome is about ten times shorter than a diploid human genome 
Mutations in molecular markers can be present in low abundance within a high background of wild type sequence that may only differ from mutant at a single nucleotide. Several methods exist for detection of somatic mutations by real-time PCR. These methods include use of allele-specific competitive blocker PCR (Orou et al., 1995), blocker-PCR (Seyama et al., 1992), real-time genotyping with locked nucleic acids (Ugozzoli et al., 2004), the amplification refractory mutation system (Newton et al., 1989), and fluorescent amplicon generation as a novel real-time PCR technology (Amicarelli et al., 2007).

Mutated NPM1 is localised in the cytoplasm and not in the nucleus (Bolli et al., 2007; Falini et al., 2006; Liso et al., 2008; Oelschlaegel et al., 2010). Immunohistochemical detection of cytoplasmic nucleophosmin is performed with monoclonal antibody or by Western blotting (Falini et al., 2006, 2009, 2010a; Martelli et al. 2008).

\subsection{Technique of real-time PCR (RQ-PCR) for marker gene expression evaluation}

RQ-PCR permits accurate quantification of PCR products during the exponential phase of the PCR amplification process. Three main types of this analysis are used: (1) RQ-PCR using the hydrolysis probe format ("TaqMan probe"); (2) RQ-PCR using the hybridization probe format; and (3) RQ-PCR using SYBR Green Dye (Kern et al., 2005). Analysis with TaqMan probe uses 5' -3' exonuclease activity of the Thermus aquaticus (Taq) polymerase to detect and quantify the PCR product. The hydrolysis probe is positioned within the target sequence and is conjugated with a reporter fluorochrome at the 5' end and a quencher fluorochrome at the $3^{\prime}$ end. The quencher avoids the reporter from emission of a fluorescence signal as long as the probe is intact and both fluorochromes are in the close proximity. Upon amplification of the target sequence, the hydrolysis probe is displaced from the DNA strand by the Taq polymerase and subsequently hydrolysed by the $5^{\prime}-3^{\prime}$ exonuclease activity of the Taq polymerase. This results in displacement of of the reporter from the quencher and the fluorescence of the reporter becomes detectable.

Generally two quantification types (relative or absolute) in RQ-PCR are possible. A relative quantification based on relative expression of a target gene versus a reference gene is adequate for the most purposes. For absolute quantification, based either on an internal or an external calibration curve (Bustin et al., 2005; Ptaffl, 2001, Ptaffl et al. 2002), the methodology must be highly validated and the identical LightCycler PCR amplification efficiencies for standard material and target cDNA must be confirmed.

\subsection{Genes and microRNAs microarrays}

RNA was extracted using Trizol reagent and processed for Affymetrix U133 plus 2.0 GeneChip (Affymetrix, Santa Clara, CA) hybridizations. Briefly, from $5 \mu \mathrm{g}$ total RNA, double-stranded cDNA was prepared with the use of the T7-Oligo(dT) primer (Affymetrix). In vitro transcription for amplification and biotinylation of the RNA transcript was performed with the BioArray HighYield RNA Transcript Labeling Kit (T7; Enzo Life Science, Farmingdale, NY). Biotin-cRNA $(10 \mu \mathrm{g})$ was fragmented and hybridized onto the U133 plus 2.0 GeneChip for 16 hours at $45^{\circ} \mathrm{C}$ and labelled with $\mathrm{Cy}$-3-streptavidin conjugate according to manufacturer protocols. Scanned images were converted to CEL files using GCOS software (Affymetrix). For the miRNA microarray chips, biotinylated first-strand cDNA was synthesized in reverse transcription from 2.5 to $5.0 \mu \mathrm{g}$ total RNA using biotin-labeled random octamer oligo primer from pretreatment $\mathrm{BM}$ and blood mononuclear cell samples and hybridized to miRNA microarray chip KCC/TJU containing 368 probes in triplicate, 
corresponding to 245 human miRNA genes. After hybridization for 18 hours at $25^{\circ} \mathrm{C}$ and washing, direct detection of the biotin-containing transcripts by streptavidin-Alexa647 conjugate was done and processed slides were scanned. Expression profiles were analyzed in GENESPRING software(Silicon Genetics, Redwood City, CA).

\section{Mutations in the molecular markers}

\subsection{Mutations in the NPM1 gene}

Nucleophosmin (NPM1, also called nucleolar protein B23, numatrin or NO38) is a multifunctional phosphoprotein which contains 294 amino acids (Okuwaki et al., 2006). NPM1 is one of the three nucleophosmin isoforms which are generated through alternative splicing. NPM1 resides predominantly in the nucleoli, but also continuously shuttles between nucleus and cytoplasm (Frehlick et al., 2006). The NPM1 gene is located on chromosome 5q35 in humans and is composed of 12 exons (Chan et al., 1989). NPM1 is essential for processing and transportation of ribosomal RNA and proteins, molecular chaperoning, and regulation of the stability of tumor suppressors, such as p53 and ARF (Borer et al., 1989; Colombo et al., 2002; Enomoto et al., 2006; Herrera et al., 1995; Li \& Hann, 2009; Maggi et al., 2008; Savkur \& Olson, 1998; Yu et al., 2006). The ARF tumor suppressor is a protein that is transcribed from an alternate reading frame of the inhibitor of cyclindependent kinase CDK4. NPM1 can affect DNA replication, repair and transcription by interacting with the components of chromatin such as histones and chromatin remodeling proteins (Amin et al., 2008a,b; Angelov et al., 2006; Koike et al., 2010). NPM1 plays important roles in cell cycle (Ugrinova et al., 2007; Xiao et al., 2009). NPM1 may preferentially promote ribosome biogenesis in G1, facilitate DNA replication during S-phase while supporting chromosome segregation in mitosis (Hisaoka et al., 2010).

Almost $40 \%$ of CN-AML patients have mutations in exon 12 of the NPM1 gene which result in loss of tryptophan residues normally required for NPM1 binding to the nucleoli and in the generation of an additional nuclear export signal motif at the C-terminus of NPM1 which causes its abnormal cytoplasmic localization (Bolli et al., 2007; Falini et al., 2006; Liso et al., 2008; Oelschlaegel et al., 2010). These mutations are the most common genetic alterations in adult CN-AML patients and are associated with female sex, higher white blood count, increased blast percentage, and low or absent CD34 expression. Cytoplasmic nucleophosmin leukemic mutant is also rarely generated by a exon-11 NPM1 mutation (Albiero et al., 2007). Acute myeloid leukemias with mutated NPM1 (NPM1c+) have distinct characteristics, including a significant association with a normal karyotype, involvement of different hematopoietic lineages, a specific gene-expression profile and clinically, a better response to induction therapy and a favorable prognosis (Meani \& Alcalay, 2009; Rau \& Brown, 2009, Falini et al., 2010). NPM1c+ maintains the capacity of wild-type NPM to interact with a variety of cellular proteins, and impairs their activity by delocalizing them to the cytoplasm. NPM1c + specifically inhibits the activities of the celldeath proteases, caspase- 6 and -8 , through direct interaction with their cleaved, active forms, but not the immature procaspases. NPM1c+ not only affords protection from death ligand-induced cell death but also suppresses caspase-6/-8-mediated myeloid differentiation (Leong et al., 2010).

After the discovery of NPM1-mutated AML in 2005 and its subsequent inclusion as a provisional entity in the 2008 World Health Organization classification of myeloid neoplasms, several controversial issues remained to be clarified (Falini, 2011). It was unclear 
whether the NPM1 mutation was a primary genetic lesion and whether additional chromosomal aberrations and multilineage dysplasia (MLD) had any impact on the biologic and prognostic features of NPM1-mutated AML. Moreover, it was uncertain how to classify AML patients who were double-mutated for NPM1 and CEBPA. Recent studies have shown that: (1) the NPM1 mutant perturbs hemopoiesis in experimental models; (2) leukemic stem cells from NPM1-mutated AML patients carry the mutation; and (3) the NPM1 mutation is usually mutually exclusive of biallelic CEPBA mutations. Moreover, the biologic and clinical features of NPM1-mutated AML do not seem to be significantly influenced by concomitant chromosomal aberrations or multilineage dysplasia. NPM1-mutated AML with and without MLD showed overlapping immunophenotype (CD34 negativity) and gene expression profile (CD34 down-regulation, homeobox (HOX) genes up-regulation). Altogether, these pieces of evidence point to NPM1-mutated AML as a founder genetic event that defines a distinct leukemia entity accounting for approximately one-third of all AML. Distinctive gene expression and microRNA signatures were found associated with AML bearing cytoplasmic mutated NPM1 (Becker et al., 2010; Garzon et al., 2008, Verhaak et al., 2005).

Approximately $40 \%$ of patients with NPM1 mutations also carry FLT3 internal tandem duplications (FLT3-ITD). Patients with NPM1 mutations, who did not also have FLT3 mutation have generally more favorable prognosis (Gale et al., 2008; Scholl et al., 2008; Luo et al., 2009). The favourable prognosis of NPM1-mutated/FLT3-ITD negative patients might be explained by a higher bax/bcl-2 ratio (Del Poeta et al., 2010). These patients respond to induction therapy and stay in remission more likely. These patients may be exempted from allogenic hematopoietic stem cell transplantation during the first complete remission because their outcome after conventional consolidation chemotherapy is the same as after allogenic transplantation. However, patients with NPM1 mutations who also carry FLT3 mutation have bad prognosis.

Moreower, NPM1 mutations due to their frequency and stability, may be used for minimal residual disease monitoring in AML patients with a normal karyotype (Bacher et al., 2009; Schnittger et al., 2009; Dvorakova et al., 2010).

\subsection{FLT3 mutations}

The feline c-fms proto-oncogene product is a $170 \mathrm{kd}$ glycoprotein with associated tyrosine kinase activity. Fms-like tyrosine kinase 3 (FLT3) and its ligand (FL) are important in hematopoietic progenitor cell proliferation and differentiation (Gilliland \& Griffin, 2002). As a result of ligand binding, FLT3 receptor on the cell surface of hematopoietic progenitors dimerizes, resulting in activation of its tyrosine kinase domain, receptor autophosphorylation, and recruitment of downstream signaling molecules such as signal transducer and activator of transcription 5a (STAT5a), and the MAPK (mitogen activated protein kinases) pathways leading to proliferative and pro-survival effects.

Internal tandem duplication (ITD) of base pairs within the juxtamembrane coding portion or point mutations in the second kinase domain occur in approximately $30 \%$ of patients with newly diagnosed AML and result in constitutive activation of the FLT3 gene on chromosome 13q12 ( Nakao et al., 1996; Naoe \& Kiyoi, 2004; Yamamoto et al., 2001). FLT3 mutations in the case of ITDs are associated with chemoresistance in the leukemic stem cells, shorter disease-free survival and overall survival and higher rate of relapse (Frohling et al., 2002; Ravandi et al., 2010; Whitman et al., 2010). Specific gene expression signature associated with FLT3-ITD was described (Bullinger et al., 2008; Whitman et al., 2010). 
Overexpression of FLT3, homeobox genes and immunotherapeutics targets and decreased expression of erythropoiesis-associated genes is connected with FLT3-ITD. The prognostic significance of FLT3 point mutations is less clear with conflicting results (Mead et al., 2008). In clinical practice, a frequent approach to patients with poor prognostic AML is to offer allogenic stem cell transplantation (SCT). Gale et al. (2005) found no benefit from any form of transplantation consolidation for patients with FLT3-ITD. Several inhibitors of FLT3 have entered clinical trials and are studied alone or mainly in combination with chemotherapy (Kindler et al., 2010; Small, 2008; Weisberg et al., 2009; Wiernik, 2010).

\subsection{CCAAT/enhancer binding protein alpha (CEBPA) mutations}

The CCAAT/enhancer binding protein alpha $(\mathrm{C} / \mathrm{EBPa})$ is the founding member of a family of related leucine zipper transcription factors that play important roles in myeloid differentiation (Friedman et al., 2007; Keeshan et al., 2003; Pabst \& Mueller, 2007; Suh et al, 2006; Tenen et al. 1997). Members of this family consist of N-terminal transactivation domains, a DNA-binding basic domain, and a C-terminal leucine rich dimerization region (Fig. 1).

\section{transcription factor $\mathrm{C} / \mathrm{EBP} \alpha$}

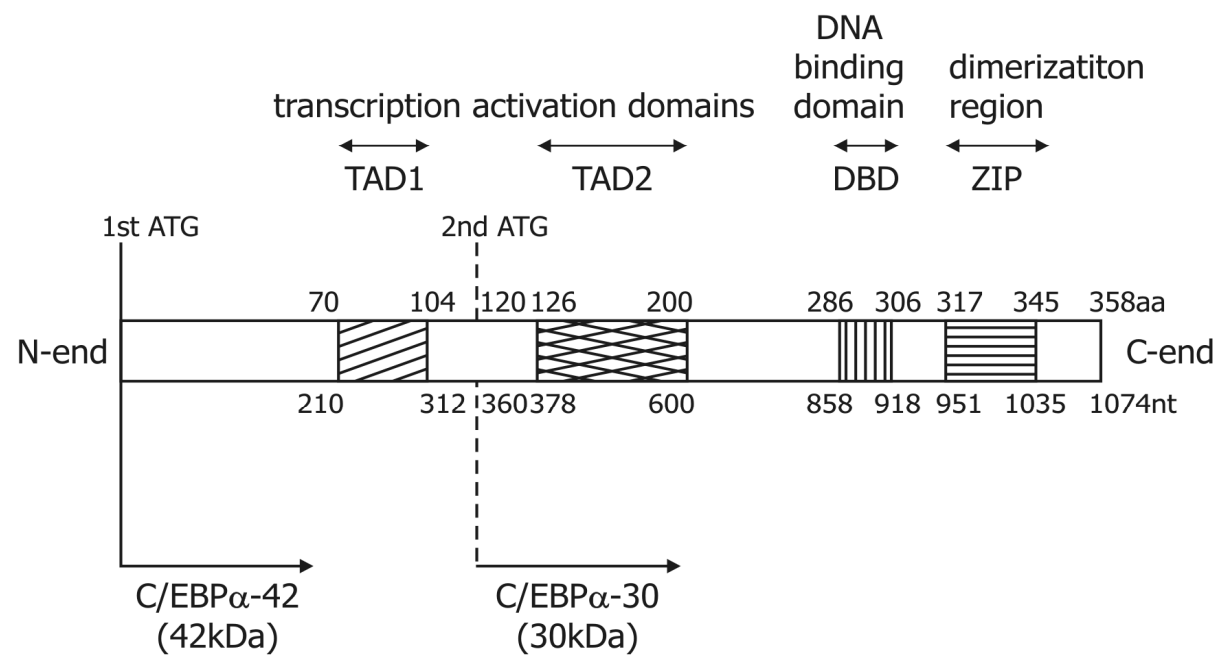

Fig. 1. The location of functional domains within the C/EBPa protein. Numbers directly above the schema indicate the amino acids of the human C/EBPa. Numbers directly under the schema indicate nucleotides (GenBank Accession No. NM_004364.2). The full-length 42 $\mathrm{kDa}$ form of $\mathrm{C} / \mathrm{EBPa}$ protein and the shorter, dominant negative $30 \mathrm{kDa}$ form of this protein are also shown.

The dimerization domain, known as "leucine zipper", contains leucine repeats that intercalate with leucine repeats of the dimer partner forming a coiled coil of a helices in parallel orientation. C/EBPa mRNA is translated into two major proteins, C/EBPa p42 (42 
$\mathrm{kDa})$ and C/EBPa p30 (30 kDa) by ribosomal scanning mechanism in which a fraction of ribosomes ignore the first two AUG codons and initiate translation at the third AUG codon located 357 nucleotides downstream of the first one (Fig. 1). The $30 \mathrm{kDa}$ protein lacks the transactivating domain TAD1 (Fig. 1) and was shown to inhibit DNA binding and transactivation by C/EBPa p42 (Pabst et al., 2001). C/EBPa p30 fails to induce myeloid differentiation (D'Alo' et al., 2003; Friedman et al., 2007). Targeted inactivation of C/EBPa in mice demonstrates its importance in the proper development and function of liver, adipose tissue, lung and hematopoietic tissues (Flodby et al., 2006; Wang et al., 1995; Zhang et al., 1997). C/EBPa is highly expressed in these differentiated tissues where it controls differentiation-dependent gene expression and inhibits cell proliferation (Fuchs 2007). Learning more about the precise molecular functions of the C/EBPa protein and how these are affected by leukemogenic mutations should lead to an improved understanding of the cellular functions that are disrupted in patients with AML.

CEBPA mutations were found in 10-19\% of CN-AML patients (Gombart et al., 2002; Fröhling et al., 2004; Fuchs et al., 2008, 2009; Lin et al., 2005; Pabst et al., 2001; Preudhomme et al., 2002). Two kinds of mutations were mainly described: 1) truncating, frameshift mutations occuring near the $\mathrm{N}$-terminus in one of the two transcription activations domais (TAD1 and TAD2) on one allele and 2) in-frame insertions or deletions clustering within the C-terminal basic domain- leucine zipper (DBD and ZIP) on the other allele. Often, CN-AML patients with CEBPA mutations belong to FAB (French -American -British) subtypes M1 or M2 and have one mutation towards $\mathrm{N}$-end and one towards $\mathrm{C}$-end but other cases of mutations were also detected. Kato et al. (2011) showed that a mutation of CEBPA in one allele was observed in AML after MDS while the two alleles are mutated in de novo AML. Favourable impact of CEBPA mutations was mainly observed in patients with biallelic mutation and with lack of FLT3-ITD (Dufour et al., 2010; Hou et al., 2009; Pabst et al., 2009; Radomska et al. 2006; Taskesen et al., 2011; Wouters et al., 2009).

\subsection{Partial tandem duplications of the $M L L$ gene}

The mixed lineage leukemia gene ( $M L L$, also known as $A L L-1$ or $H R X)$, located on chromosome 11q23, encodes a histone methyltransferase and is frequently rearranged in AML. Wild-type MLL is schematicly presented in Fig. 2. To date, MLL has been found in more than sixty different translocations with different fusion partners (Basecke et al., 2006; De Braekeleer et al., 2005). Partial tandem duplications of the MLL gene were first observed in CN-AML by Caligury et al., 1994. These duplications consist of an in-frame repetition of $M L L$ exons in a $5^{\prime}-3^{\prime}$ direction and lead to the change of the resulting transcript and protein. MLL-PTD are named according to the fused exons (mainly e9/e3, e10/e3, e11/e3).

MLL-PTD are detectable in 5\%-11\% of patients with CN-AML (Döhner et al., 2002; Döhner \& Döhner 2008; Schnittger et al., 2000; Steudel et al., 2003). MLL-PTD have been found also in peripheral blood and bone marrow samples of healthy adults. However in contrast to the MLL-PTD in AML, MLL-PTD in healthy adults had often unusual exon fusions and showed an ladder on gel electrophoresis after the nested RT-PCR (Basecke et al., 2006; Marcucci et al., 1998; Schnittger et al., 1998). MLL-PTD cooperate with silencing of the MLL wild-type allele by epigenetic mechanisms. MLL-PTD contribute to leukemogenesis through hypermethylation of DNA and epigenetic silencing of tumor suppressor genes (Dorrance et al., 2006; Whitman et al., 2008a). Inhibitors of DNA methyltransferase and histone acetylase inhibitors and their combination can re-activate the wild-type allele in MLL-PTD-positive blasts (Whitman et al., 2005). 


\section{MLLWT}

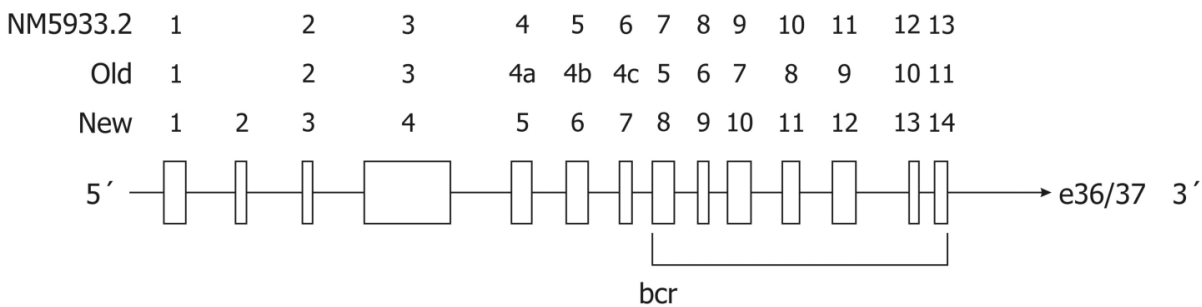

Fig. 2. Exon-intron structure of the wild-type MLL gene involved in tandem and nontandem duplications. The nomenclature is different in various studies (Nilson et al., 1996; Strout et al., 1998, Śárová et al., 2009). The MLL gene as a whole contains 36 or 37 exons according to the different nomenclatures and the resulting product of its expression contains 3969 amino acids. In the case of MLL-PTD e9/e3 are exons and introns between exons 3 and 9 inserted between exons 9 and 10 of the wild-type MLL and are duplicated by this way (the fusion of introns 2 and 9).

MLL-PTD are associated with shorter duration of the complete remission, shorter relapsefree survival and event-free survival, but MLL-PTD have no effect on overall survival Döhner \& Döhner.

\subsection{Wilms' tumor 1 (WT1) mutations}

The Wilms tumor 1 (WT1) gene is located on chromosome $11 \mathrm{p} 13$ and encodes a zinc-finger transcriptional regulator that can function as tumor suppressor in patients with the WAGR (Wilms' tumor predisposition, aniridia, genitourinary abnormalities, and mental retardation) tumor predisposition syndrome (Haber et al., 1990) and as an oncogene in various leukemias, as well as other cancers (Ariyaratana \& Loeb, 2007; King-Underwood et al., 1996; Miwa et al., 1992; Yang et al., 2007). Mutations in WT1 gene were found in approximately 10\% of AML patients (Hou et al., 2010; Gaidzik et al., 2009; Owen et al., 2010; Paschka et al., 2008; Virappane et al. 2008). Mutations are mainly localized in zinc-finger domains in exons 7 and 9 but can be also found in exons 1,2,3, and 8. The truncated WT1 protein is the result of frameshift mutations in exon 7. Truncated WT1 is without nuclear localization signal and does not bind to other interacting proteins as p53 and its homologue p73. Frameshift mutations in exon 9 are less frequent but there are also missense mutations. WT1 mutations have been reported as an adverse prognostic factor in adult CN-AML and independently predict for poor outcome (Hou et al., 2010; Gaidzik et al., 2009; Owen et al., 2010; Paschka et al., 2008; Renneville et al., 2009; Virappane et al. 2008). WT1 mutations lead to inferior rate of complete remission, higher incidence of relapse abd to shorter relapse-free survival and overall survival. A recent study demonstrated that a single nucleotide polymorphism SNP rs16754 in the WT1 mutational hotspot predicted favorable outcome in CN-AML (Damm et al. 2010).

\subsection{Isocitrate dehydrogenase 1 and 2 (IDH1, IDH2) gene mutations}

Mardis et al. (2009) found recurring mutations in codon 132 of the IDH1 gene by sequencing a whole AML genome as described in paragraph 2.2. The protein encoded by this gene is the 
enzyme that catalyzes the oxidative carboxylation of isocitrate to a-ketoglutarate leading to nicotinamide adenine dinucleotide phosphate production in Krebs cycle and was found in the cytoplasm and peroxisomes (Geisbrecht \& Gould, 1999). Three classes of IDH isoenzymes exist in mammalian cells (two forms of mitochondrial IDH and cytosolic IDH). IDH1 gene is localized to chromosome band 2q33.3 and IDH2 gene to chromosome band 15q26.1 (Narahara et al.,1985; Oh et al.,1996). IDH2 encodes the mitochondrial isoform that uses nicotinamide adenine dinucleotide phosphate as a cofactor. The same cofactor is also used by IDH1.

Most cancer-associated enzyme mutations result in constitutive activation or inactivation of the mutated enzyme. IDH1 and IDH2 mutations result in the new enzyme activity, production of 2-hydroxyglutarate, not shared by wild type enzymes (Ward et al., 2010). This accumulation of 2-hydroxyglutarate induces global DNA hypermethylation, disrupts TET2 function because this enzyme is a-ketoglutarate-dependent, and impairs hematopoietic differentiation (Figueroa et al., 2010). TET2 is a homolog of the gene originally discovered at the chromosome ten-eleven translocation (TET) site in a subset of patients with AML. TET2 catalyzes the conversion of methylcytosine to 5-hydroxymethylcytosine, suggesting a potential role for TET proteins in epigenetic regulation. Blocking the accumulation of 2hydroxyglutarate through the inhibition of mutant IDH enzymes could represent a therapeutic target (Dang et al. , 2010; Cazola 2010).

IDH1 mutations at codon R132 occur in CN-AML patients with a frequency of $5.5 \%$ to $11 \%$ (Boissel et al., 2010; Gross et al., 2010; Patel et al., 2011; Schnittger et al., 2010; Wagner et al., 2010). A strong association between IDH1 mutations and the NPM1 mutation and M1 FAB subtype was observed. On the other hand, IDH1 mutations are inversely associated with the M4 FAB subtype and expression of HLA-DR, CD13 and CD14 antigens. The prognostic impact of IDH1 mutations in CN-AML is associated with a higher risk of relapse and a shorter overall survival (Abbas et al., 2010; Boissel et al., 2010; Marcucci et al., 2010; Paschka et al., 2010; Schnittger et al., 2010). Others (Chou et al., 2010a; Patel et al., 2011; Wagner et al., 2010), however, found no significant impact of IDH1 mutations on CN-AML patients outcome. IDH2 mutations in exon 4, including mainly codon R140 and in rare cases codon R172, had no prognostic impact (Thol et al., 2010). Recent study of Chou et al. (2011) showed high stability of IDH2 mutations during disease evolution and their connection with favorable prognosis. Contrary to this observation, Boissel et al. (2010) found IDH2 mutations independently associated with a higher risk of relapse and shorter overall survival. The prognostic impact of IDH1 mutations and IDH2 mutations needs further study as very controversial results were obtained. Green et al. (2010) observed no difference in outcome between IDH1 mutated and nonmutated patients when the results were stratified by an NPM1 mutation status but an adverse outcome for IDH1 mutated patients when the results were correlated with FLT3-ITD mutation.

\subsection{Mutations in gene for DNA methyltransferase 3A (DNMT3A)}

About $22 \%$ of CN-AML patients have DNMT3A mutations. The most common DNMT3A mutation affects amino acid R882 but other parts of DNMT3A gene are also affected by mutations in CN-AML patients (Ley et al., 2010). Aberrant DNA methylation contributes to the pathogenesis of cancer (Rodríguez-Paredes \& Esteller 2011; Taberlay \& Jones, 2011; Watanabe \& Maekawa, 2010). Clusters of CpG dinucleotides in promoters of tumorsupppressor genes are hypermethylated in cancer genomes and this hypermethylation 
results in reduced expression of the downstream gene. However, inhibition of DNA methyltransferases is only one potential mechanism of function of demethylating agents (5azacytidine and decitabine). DNMT3A mutations do not change 5-methylcytosine content in AML genomes but are associated with poor survival. DNMT3A mutations are in many cases found together with FLT3 mutations, NPM1 mutations and IDH1 mutations. All these combinations of mutations have a significantly worse outcome.

\subsection{RAS mutations in CN-AML}

Ras-signaling cascade contributes to the molecular pathogenesis of myeloproliferative disorders (Chan et al., 2004). Ras oncogenes (small GTPases) regulate mechanism of proliferation, differentiation, and apoptosis. NRAS (neuroblastoma RAS) mutations were detected in $9 \%$ of adult CN-AML patients and 14\% of CN-AML patients younger than 56 or 60 years (Bacher et al., 2006; Bowen et al., 2005). There was no prognostic impact of these mutations in most studies (Gaidzik \& Döhner, 2008; Ritter et al., 2004; Schlenk \& Döhner, 2009). Mutations in other members of Ras family are rare in CN-AML and there was also no consistent effect on prognosis but the presence of Ras mutations appears to sentisize AML blasts to high dose cytarabine in vivo (Motyckova \& Stone 2010).

\subsection{Other gene mutations in CN-AML}

Mutations in RUNX1 have been shown in approximately 10\%-13\% of CN-AML (Döhner \& Döhner, 2008, Tang et al., 2009). These mutations were positively associated with MLL-PTD and negatively associated with NPM1 and CEBPA mutations. They predict ed a lower complete remission rate and shorter disease-free and overall survival .

TET2 (ten-eleven-translocation) first described in 2008, include frameshift, nonsense and missense mutations lying across several of its 12 exons located on chromosome 4q24 (AbdelWahab et al., 2009; Bacher et al., 2010; Mohr et al., 2011; Nibourel et al., 2010). The direct influence of mutations in TET2 on patient survival in CN-AML remains a disputable issue. TET2 mutations were revealed in 10\%-25\% of CN-AML patients. Abdel-Wahab et al. (2009) showed a decreased survival rate in mutated TET2 in comparison with wild-type TET2 group of CN-AML. However, Nibourel et al. (2010) did not find significant impact of TET2 mutation on clinical outcome of CN-AML patients but they observed mutated TET2 strongly associated with mutated NPM1. Recently, Metzeler et al. (2011) have found TET2 mutations in $23 \%$ of $\mathrm{CN}$-AML patients and these mutations were associated with older age. In favorable-risk group of CN-AML patients with CEBPA mutation and/or mutated NPM1 without FLT3-ITD, TET2-mutated patients had shorter event-free survival, lower complete remission rate and shorter disease-free and overal survival. In $\mathrm{CN}$-AML patients with intermediate risk with wild-type CEBPA and wild-type NPM1 without FLT3-ITD, TET2 mutations were not associated with outcomes.

CBL (Casitas B-cell lymphoma) mutations were identified in rare cases of CN-AML (Bacher et al., 2010; Makishima et al., 2009; Reindl et al., 2009). Cbl is E3 ubiquitin ligase involved in degradation of activated receptor tyrosine kinases, including Src kinases (Makishima et al., 2009). Presence of these mutations was suggested to be involved in aberrant FLT3 expression. FLT3 ligand-dependent hyperproliferation of CBL mutant cells could be abrogated by treatment with the specific inhibitor, midostaurin (PKC412).

Mutations in the additional sex comb-like 1 (ASXL1) gene were analyzed in exon 12 in $\mathrm{CN}$ AML patients and $8.9 \%$ mutations were detected (Chou et al., 2010b). This mutation was 
closely associated with older age, male sex, RUNX1 mutation and expression of human leukocyte-antigen-DR and CD34 (Chou et al., 2010b; Rocquain et al., 2010). Association with FLT3-ITD, NPM1 mutation, WT1 mutation, and expression of CD33 and CD15 was not detected. ASXL1 mutated patients had a shorter overall survival than patients without this mutation, but the mutation was not an independent adverse prognostic factor in multivariete analysis.

Phosphoinositide phospholipase C $\beta 1$ (PI-PLC $\beta 1$ ) gene mutations are very rare in CN-AML (Damm et al., 2010). Follo et al. (2009) described greater representation of these mutations (monoallelic deletions) in AML and their association with a worse clinical outcome.

\section{Overexpression of marker genes with prognostic relevance}

Alterations in the expression of genes belonging to signal transduction pathways as well as transcription factors are known to play a functional role in the pathogenesis of AML. Therefore, these marker genes are implicated in the process of leukemogenesis and their overexpression may be useful to predict outcome in CN-AML patients.

\subsection{WT1 gene expression}

The WT1 gene overexpression was found in several leukemias, including AML (Cilloni et al., 2009). WT1 mRNA levels in the peripheral blood can predict relapse after achieving complete remission, and its levels after consolidation therapy are closely correlated with disease-free and overall survival, and with early relapse (Cilloni et al., 2009; Gianfaldoni et al., 2010; Miyawaki et al., 2010). Monitoring of WT1 expression is significant predictor of relapse in AML patients after hematopoietic cell transplantation (Lange et al., 2011).

\subsection{BAALC (brain and acute leukemia, cytoplasmic) expression}

The BAALC gene, located on chromosome $8 \mathrm{q} 22.3$, is primarily expressed in neuroectodermderived tissues and in hematopoietic precursors and encodes a protein with unknown function (Baldus et al., 2003, 2006; Langer et al., 2008; Santamaria et al., 2010). High level of $B A A L C$ expression showed a higher refractoriness to induction treatment, lower complete remission rate after salvage therapy and lower overall survival and relapse - free survival in intermediate-risk AML (Santamaria et al., 2010). The BAALC expression is considered an independent prognostic factor in CN-AML. High BAALC expression was associated with FLT3-ITD, and high ERG expression in multivariable analysis (Baldus et al., 2006). High $B A A L C$ expression is also connected with overexpression of genes involved in drug resistance (MDR1) and stem cell markers (CD133, CD34, KIT). In low BAALC expressers, genes associated with undifferentiated hematopoietic precursors and unfavorable outcome predictors were downregulated, while $H O X$-genes and HOX-gene-embedded-miR were upregulated (Schwind et al., 2010). Global miR expression analysis did not reveal significant differences between different rate BAALC expression groups (Langer et al., 2008). Inverse association between the expression of miR148a and BAALC was revealed.

\subsection{ERG (v-ets erythroblastosis virus E26 oncogene homolog) expression}

ETS-related gene $(E R G)$, located at chromosome band 21q22, is downstream effector of signaling transduction pathways involved in the regulation of cell proliferation, differentiation, and apoptosis (Marcucci et al., 2005,2007; Mrózek et al., 2007; Metzeler et al. 2009, Schwind et al., 2010). CN-AML patients with overexpression of ERG have been 
reported to have a poor clinical outcome. When combined with other known prognostic markers, ERG expression can improve the molecular risk-based stratification of patients with CN-AML. Low ERG expression is associated with downregulation of genes involved in the DNA-methylation machinery, upregulation of miR148a, which targets DNA methyltransferase 3B (DNMT3B) and with better outcome (Schwind et al., 2010).

\subsection{MN1 (meningioma 1) expression}

MN1 is located at 22q11 and its overexpression is associated with lower response rate after first course of induction therapy and poor clinical outcome for CN-AML patients. Moreover, high MN1 expression was connected with a higher relapse rate and worse relapse-free and overall survival (Grosveld, 2007; Heuser et al., 2006; Langer et al., 2009). MN1 expression levels were directly correlated with $B A A L C$ expression levels and with the expression of genes reported as associated with a BAALC expression signature, specifically with expression of CD34 and ABCB1 (MDR1) and several other genes (Langer et al., 2008, 2009). MN1 expression levels were negatively connected with expression of $H O X$ genes and with NPM1 mutated CN-AML (Langer et al., 2009). MN1-associated miR-expression signature comprises $15 \mathrm{miR}$, expression of $8 \mathrm{miR}$ ( $h s a-m i R-126$ family) was positively correlated and expression of $7 \mathrm{miR}$ (hsa-miR-16, hsa-miR-19a and $h s a-m i R-20 a$, all members of miR-17-92 polycistron) negatively correlated with MN1 expression (Langer et al., 2009). MN1 overexpression confered resistance to the differentiation activity of all-trans-retinoic acid (ATRA) in AML (Heuser et al., 2007).

\subsection{EVI1 (ecotropic viral integration site 1) expression}

Human EVI1 is localized to chromosome 3 band q26, spans $60 \mathrm{~kb}$, and contains 16 exons (Goyama \&Kurokawa, 2009). High EVI1 expression occurs in approximately $8 \%$ of patients with de novo AML (Barjesteh van Waalwijk van Doom-Khosrovani et al., 2003). High EVI1 expression was observed not only in AML carrying the chromosome 3 abnormalities, but also in CN-AML (Gröschel et al., 2010; Lugthart et al., 2008; Santamaria et al., 2009) and is in both groups connected with poor treatment response.

\subsection{Other molecular marker genes expression}

The PRAME (preferentially expressed antigen of melanoma) gene was shown to be expressed in high levels in AML. PRAME mRNA was observed in about one-third of AML cases and there was a good correlation between PRAME mRNA level and hematological remission and relapse. It may be also useful marker to detect minimal residual disease after allogenic transplantation (Paydas et al., 2005; Qin et al. ., 2009). Epping et al. (2005) showed that PRAME is a repressor of retinoic acid signaling but Steinbach et al. (2007) did not confirm this mechanism in the pathogenesis of AML. Specific immunotherapies for patients with AML using leukemia-associated antigens (LAA) as target structures might be a therapeutic option. Expression of genes for these antigens have prognostic importance (Greiner et al., 2008).

$A F 1 q$ (ALL1 fused gene from chromosome 1q) gene overexpression in CN-AML patients is associated with a significantly greater incidence of concurrent FLT3-ITD and with a poor outcome (Strunk et al., 2009). NC-AML patients with low AF1q expression had better overall survival and complete remission rate than patients with high AF1q mRNA level. 
High MLL5 (mixed lineage leukemia 5) expression is associated with a favorable outcome of CN-AML patients and enables identification of a significant proportion of patients with favorable prognosis that are not identified by other markers analyses (Damm et al., 2011). Increased expression of the phosphoinositide phospholipase C $\beta 1$ (PI-PLC $\beta 1$ ) gene is an independent prognostic factor in CN-AML and is associated with a significantly shorter overall survival but with no difference for relapse-free survival (Damm et al., 2010).

The Rho family of small GTPases, including Rho, Rac and Cdc42, functions as critical mediators of signaling pathways from plasma membrane regulating actin assembly, migration, proliferation and survival in hematopoietic cells. $\mathrm{RhoH}$ gene, also known as Translocation Three Four (TTF), encodes a 191-amino acid protein belonging to the Rho family (Gu et al., 2005; Iwasaki et al., 2008). Rho $\mathrm{H}$ functions as a negative regulator for interleukin 3 (IL3) - induced signals through modulation of the JAK-STAT (Janus KinaseSignal Transducer and Activator of Transcription)- signaling pathway (Gúndogdu et al., 2010). Low RhoH levels are connected with an upregulation of IL3- dependent cell growth, STAT5 activity and an increase of CD123 surface expression that has been described in AML patients (Gúndogdu et al., 2010). Multivariate analysis demonstrated that low expression of $\mathrm{RhoH}$ was an independent unfavorable prognostic factor for both overall and disease-free survival of AML in the intermediate risk group (Iwasaki et al., 2008).

Activation of Notch signal pathway (expression of Notch1, Jagged1 and Delta1 as members of this pathway) is associated with a poorer prognosis for AML patients with intermediate risk (Xu et al., 2010).

The Forkhead transcription factors (FOXO) are direct target of the PI3K/AKT (protein kinase B) signaling and they integrate the signals of several other transduction pathways at the transcriptional level. The PI3K/AKT/FOXO signaling pathway is up-regulated in AML. High FOXO3a expression is associated with a poorer prognosis in CN-AML (Santamaria et al., 2009) and the increased levels of both total and of highly phosphorylated FOXO3a correlate with higher proliferation and blood blasts and these high levels of FOXO3a are an adverse prognostic factor in AML (Kornblau et al., 2010).

Bone marrow neoangiogenesis plays an important pathogenetic and possible prognostic role in AML (Hou et al., 2008; Lee et al., 2007; Loges et al., 2005; Mourah et al. 2009). Multivariable analysis showed that the levels of vascular endothelial growth factor (VEGF) transcript isoform 121 (VEGF121) remained an independent prognostic factor for either event-free survivasl or overall survival (Mourah et al., 2009). High levels of VEGF121 were significantly related to a worse prognosis. Angiopoietin-2 (Ang2) gene expression represents also an independent prognostic factor in AML with intermediate risk and high Ang2 expression is associated with an unfavorable prognosis (Hou et al., 2008; Lee et al., 2007; Loges et al., 2005). High VEGFC expression appeared strongly associated with reduced complete remission rate, reduced overall and event-free survival in adult AML independent of cytogenetic risk and white blood cell count (de Jonge et al., 2010). High VEGFC expression was related to enhanced chemoresistance and predicted adverse long-term prognosis.

TGF $\beta$ (transforming growth factor beta) superfamily receptors ALK-1 (activin receptor like kinase) and ALK-5 have an important role in endothelial cells behavior and might be involved in the pathogenesis of AML. ALK-1 and ALK-5 are both expressed by the majority of AML patients. ALK-5 expression has a significant negative impact on complete remission achievment and overall survival of AML patients (Otten et al., 2011). 
Dysregulation of the Wnt/ $\beta$-catenin pathway has been observed in various malignancies, including AML. Overexpression of $\beta$-catenin is an independent adverse prognostic factor in AML (Chen et al., 2009; Ysebaert et al., 2006).

Chemokine (C-X-C motif) receptor 4 (CXCR4) retains hematopoietic progenitors and leukemia cells within the marrow microenvironment. Multivariate analysis revealed CXCR4 expression as an independent prognostic factor for disease relapse and survival (Konoplev et al., 2007; Spoo et al., 2007; Tavernier-Tardy et al., 2009). Low CXCR4 expression correlated with a better prognosis, resulting in a longer relapse-free and overall survival.

Many studies of AML have linked the overexpression of ABCB1 (also named permeability glycoprotein, Pgp), a member of ATP-binding proteins coded by the multi-drug resistance gene (MDR1), to poor prognosis (Leith et al., 1997; Steinbach \& Legrand, 2007; Trnkova et al., 2007). Other drug-resistance proteins BCRP (breast cancer resistance protein, also named ABCG2) and LRP (lung resistance protein) have also an adverse impact (Dimiani et al., 2010; Huh et al., 2006).

\section{Gene expression profiling in CN-AML}

Gene expression profiling (GEP) was described twelve years ago by Golub et al. (1999). GEP analyses on the basis of microarrays allow the simultaneous characterization of thousands of genes. GEP is useful for the classification of leukemias. In CN-AML, microarray GEP has been applied to identify expression signatures in order to predict clinical outcome within this very heterogeneous group of patients.

Bullinger et al. (2004) and Radmacher et al. (2006) defined by GEP two novel molecular subclasses of CN-AML with significant differences in survival times with respect to the presence or absence of FLT3 mutations and the FAB subtypes.

NPM1 gene mutations are connected with specific gene expression pattern in CN-AML (Alcalay et al., 2005; Becker et al., 2010; Garzon et al., 2008; Verhaak et al., 2005; Wilson et al., 2006). This specific gene expression signature was characterised by the activation of homeobox $(H O X)$ genes including a particular subset of homeobox TALE (three amino acid loop extension) genes distinguish themselves from typical homeodomains containing genes. Downregulated in the NPM1 mutations group were genes whose low expression is associated with better prognosis in CN-AML as $B A A L C, M N 1, E R G$, and multidrug resistance genes.

Comparison of gene expression between biallelic CEBPA mutation and monoallelic CEBPA mutation AML was described by Dufour et al. (2010). Expression of multiple members of the homeobox gene family (HOXA5, HOXA9, HOXA10, HOXB2, and HOXB6), CD34, and lymphoid markers CD6, CD52, and TSPO (gene for translocator protein, benzodiazepine receptor) is downregulated in CN-AML patients with biallelic CEBPA mutation.

Specific gene expression signatures associated with FLT3-ITD and FLT3-TKD (mutations in the tyrosine kinase domain) were described (Bullinger et al., 2008; Neben et al., 2005; Whitman et al., 2008b, 2010). Overexpression of FLT3, homeobox genes (HOXB3, HOXB5, $P B X 3$, MEIS1), and immunotherapeutic targets (WT1, CD33) and underexpression of leukemia associated (MLLT3, TAL1) and erythropoiesis-associated genes (GATA3, EPOR, ANK1, HEMGN) is typical for FLT3-ITD, whereas overexpression of gene for transcription factor FOXA1 containing forkhead box was observed in FLT3-TKD (Neben et al., 2005, Whitman et al., 2010). Whereas the predictive value for FLT3-ITD was relatively high (77\%), the high number of false predictions eliminates GEP as an investigational tool for research 
studies waiting on an entrance to clinical practice and decision making (Marcucci et al., 2011a; Verhaak et al., 2009; Wouters et al., 2009). GEP technique seems not to be in future a primary diagnostic tool but will be used in many cases as a confirmative method.

\section{MicroRNA expression profiling}

MicroRNAs (miRs) are small noncoding RNAs of 19 to 25 nucleotides which function as negative regulators of gene expression by causing target mRNA cleavage or by interfering with target mRNA translation. Dysregulation of miRs plays an important role in the pathogenesis of many cancers based on their involvement in basic cellular functions (NanaSinkam \& Croce, 2010). In addition, miRs have the capacity to target tens to hundreds of genes simultaneously. Thus, they are attractive candidates as prognostic biomarkers and therapeutic targets in cancer.

MiR expression signatures have been correlated with recurrent molecular aberrations in AML. NPM1 mutations associate with upregulation of miR10a, miR10b, and miR196a, all lying in the genomic cluster of HOX genes that are overexpressed (Becker et al., 2010, Garzon et al., 2008). Upregulation of miR181a and miR181b expression is associated with CEBPA mutations in CNAML (Marcucci et al., 2008; 2009; 2011b). FLT3-ITD was observed to be associated with miR155 upregulation and miR144 and miR451 downregulation (Whitman et al., 2010). Genome-wide profiling identified aberrantly expressed miR associated with R172 IDH2 mutated CN-AML patients (Marcucci et al., 2010). The most upregulated miR genes were genes of miR125 family (miR125a and miR125b), miR1 and miR133. The most downregulated miR genes were miR194-1, miR526, miR520a-3p, and miR548b.

Recent studies have also shown that clinical outcome in CN-AML is affected by changes in miR expression. Overexpression of miR20a, miR25, miR191, miR199a and miR199b adversely affected overall survival (Garzon et al., 2008).

\section{DNA methylation arrays}

DNA cytosine methylation in CpG islands regulates gene expression. Aberrant methylation of specific genes was observed in cancer including leukemia, although little is known about the mechanisms of this specific gene sets methylation. Genome-wide promoter DNA methylation profiling revealed unique AML subgroups and methylation patterns that are associated with clinical outcome (Bullinger \& Armstrong, 2010; Figueroa et al., 2010). DNA methylation profiles segregates patients with CEBPA mutations from other subtypes of leukemia and defined four epigenetically distinct forms of AML with NPM1 mutations. Epigenetic modification of the CEBPA promoter regions was also described and CEBPA hypermethylation appeared to be favorable prognostic marker in addition to NPM1 mutation with lack of FLT3-ITD and CEBPA bi-allelic, double mutations (Hackanson et al., 2008; Lin et al., 2010; Szankasi et al., 2011). Lugthart et al. (2011) found that the promoter DNA methylation signature of EVI1 AML blast cells differed from normal bone marrow cells and other AMLs and contained many hypermethylated genes. EVI1 was observed to physically interact with DNA methyltransferases $3 \mathrm{~A}$ and $3 \mathrm{~B}$ and colocalize with them in nuclei and complex is involved in EVI1-mediated transcriptional repression. Cases with the significantly higher levels of EVI1 are associated with many more methylated genes (Lugthart et al., 2011). 


\section{Conclusion and future directions}

CN-AML is very heterogeneous on the molecular level and harbours many genetic alterations that define new molecular subgroups. This molecular heterogeneity of CN-AML is not fully reflected in current classification systems (Vardiman et al. 2008, Döhner et al., 2010). Molecular markers with prognostic significance are very important for future therapies. Decision over whether to allograft a patient in first complete remission depends on the evaluation in a risk/benefit analysis in prognostic scoring system (Smith et al., 2011). The favorable cytogenetic risk group is now supplemented by CN-AML with mutant NPM1 or biallelic CEBPA mutations in the absence of FLT3-ITD (Döhner et al., 2010). These CNAML patients may not need to be referred for allogenic stem cell transplantation in first complete remission (Burnett et al., 2011). Low expression of BAALC is also associated with favorable outcome in CN-AML (Santamaria et al., 2010), but not in association with FLT3, NPM1, and CEBPA mutations and may not be prognostic in older patients (Langer et al., 2008). Low BAALC expression is an important factor for complete remission achievment and longer disease-free survival. Even better overall survival is reached in CN-AML patients who had low ERG expression in addition to low BAALC expression (Burnett et al., 2011). The similarity of $B A A L C$ and ERG expression signatures between younger and older $\mathrm{CN}$ AML patients and the fact that these molecular markers affect similarly outcomes in the group of younger and older than 60 years CN-AML patients sugest that older patients with favorable molecular risk factors, such as low BAALC and ERG expression, if treated more intensively, might have outcomes comparable with those of younger CN-AML patients with the same molecular markers (Schwind et al., 2010). Patients with low ERG, low EVI1, and high PRAME expression levels were also shown to have a good prognosis (Santamaria et al., 2009). Recently, Damm et al. (2011) proposed an integrative prognostic risk score (IPRS) for CN-AML patients based on clinical and molecular markers. Nine clinical, hematological and molecular factors including age, white blood cell count, mutation status of NPM1, FLT3-ITD, CEBPA, WT1 single nucleotide polymorphism SNP rs16754, and expression levels of BAALC, ERG, MN1, and WT1 (Damm et al., 2011). Other molecular markers like NRAS, MLL-PTD, WT1, IDH1, or IDH2 mutations were not significant and thus not included in the IPRS.

Genomewide search and new technologies will help to subcategorize CN-AML. Gene and microRNA signatures and DNA methylation signatures obtained in these studies may detect potential targets for new therapies.

\section{Acknowledgment}

This work was supported by the research intention VZ 00023736 from the Ministry of Health of the Czech Republic, grant MSM 0021620808 and grant LC 06044 from the Ministry of Education, Youth and Sport of the Czech Republic.

\section{References}

Abbas, S.; Lugthart, S.; Kavelaars, F.G.; Schelen, A.; Koenders, J.E.; Zeilemaker, A.; van Putten, W.J.; Rijneveld, A.W.; Löwenberg, B. \& Valk, P.J. (2010) Acquired mutations in the genes encoding IDH1 and IDH2 both are recurrent aberrations in acute myeloid leukemia: prevalence and prognostic value. Blood, Vol. 116, No. 12, (September), pp. 2122-2126, ISSN 0006-4971 
Abdel-Wahab, O.; Mullally, A.; Hedvat, C.; Garcia-Manero, G.; Patel, J.; Wadleigh, M.; Malinge, S.; Yao, J.; Kilpivaara, O.; Bhat, R.; Huberman, K.; Thomas, S.; Dolgalev, I.; Heguy, A.; Paietta, E.; Le Beau, M.M.; Beran, M.; Tallman, M.S.; Ebert, B.L.; Kantarjian, H.M.; Stone, R.M.; Gilliland, D.G.; Crispino, J.D. \& Levine, R.L. (2009) Genetic characterization of TET1, TET2, and TET3 alterations in myeloid malignancies. Blood, Vol. 114, No. 1, (July), pp. 144-147, ISSN 0006-4971

Amicarelli G, Shehi E, Makrigiorgos GM, Adlerstein D (2007). FLAG assay as a novel method for real-time signal generation during PCR: application to detection and genotyping of KRAS codon 12 mutations. Nucleic Acids Research Vol. 35, No. 19, e131, ISSN 0305-1048

Amin, M. A.; Matsunaga, S.; Uchiyama, S. \& Fukui, K. (2008a) Depletion of nucleophosmin leads to distortion of nucleolar and nuclear structures in HeLa cells. Biochemical Journal, Vol. 415, No. 3, (November), pp. 345-351, ISSN 0264-6021

Amin, M.A.; Matsunaga, S.; Uchiyama, S. \& Fukui, K. (2008b) Nucleophosmin is required for chromosome congression, proper mitotic spindle formation, and kinetochoremicrotubule attachment in HeLa cells. FEBS Letters, Vol. 582, No. 27, (November), pp. 3839-3844, ISSN 0014-5793

Angelov, D. ; Bondarenko, V.A.; Almagro, S.; Menoni, H.; Mongélard, F.; Hans, F.; Mietton, F.; Studitsky, V.M.; Hamiche, A.; Dimitrov, S. \& Bouvet P. (2006) Nucleolin is a histone chaperone with FACT-like activity and assists remodeling of nucleosomes. EMBO Journal, Vol. 25, No. 8, (April), pp. 1669-1679, ISSN 0261-4189

Ariyaratana, S. \& Loeb, D.M. (2007) The role of the Wilms tumour gene (WT1) in normal and malignant haematopoiesis. Expert Reviews in Moecular Medicine, Vol. 9, No. 14, (May), pp. 1-17, ISSN 1462-3994

Bacher, U.; Badbaran, A.; Fehse, B.; Zabelina, T.; Zander, A.R. \& Kröger, N. (2009) Quantitative monitoring of NPM1 mutations provides a valid minimal residual disease parameter following allogeneic stem cell transplantation. Experimental Hematology, Vol. 37, No. 1, (January), pp. 135-142. ISSN 0301-472X

Bacher, U.; Haferlach, C.; Schnittger, S.; Kohlmann, A.; Kern, W. \& Haferlach, T. (2010) Mutations of the TET2 and CBL genes: novel molecular markers in myeloid malignancies. Annals of Hematology, Vol. 89, No. 7, (July), pp. 643-652, ISSN 09395555

Bacher, U.; Haferlach, T.; Schoch, C.; Kern, W. \& Schnittger, S. (2006) Implications of NRAS mutations in AML: a study of 2502 patients. Blood, Vol. 107, No. 10, (May), pp. 38473853, ISSN 0006-4971

Bacher U, Kohlmann A, Haferlach C, Haferlach T. (2009) Gene expression profiling in acute myeloid leukaemia (AML). Best Practice \& Research Clinical Haematology, Vol. 22, No. 2, (June), pp. 169-180, ISSN 1521-6926

Baldus, C.D. \& Bullinger, L. (2008). Gene expression with prognostic implications in cytogenetically normal acute myeloid leukemia. Seminars in Oncology, Vol. 35, No. 4, (August), pp. 356-364, ISSN 0093-7754

Baldus, C.D.; Tanner, S.M.; Ruppert, A.S.; Whitman, S.P.; Archer, K.J.; Marcucci, G.; Caligiuri, M.A.; Carroll, A.J.; Vardiman, J.W.; Powell, B.L.; Allen, S.L.; Moore, J.O.; Larson, R.A.; Kolitz, J.E.; de la Chapelle, A. \& Bloomfield, C.D. (2003) BAALC expression predicts clinical outcome of de novo acute myeloid leukemia patients 
with normal cytogenetics: a Cancer and Leukemia Group B Study. Blood, Vol. 102, No. 5, (September), pp. 1613-1618, ISSN 0006-4971

Baldus, C.D.; Thiede, C.; Soucek, S.; Bloomfield, C.D. ; Thiel, E. \& Ehninger, G. (2006) BAALC expression and FLT3 internal tandem duplication mutations in acute myeloid leukemia patients with normal cytogenetics: prognostic implications. Journal of Clinical Oncology, Vol. 24, No. 5, (February), pp. 790-797, ISSN 0732-183X

Barjesteh van Waalwijk van Doorn-Khosrovani, S.; Erpelinck, C.; van Putten, W.L.; Valk, P.J.; van der Poel-van de Luytgaarde, S.; Hack, R.; Slater, R.; Smit, E.M.; Beverloo, H.B.; Verhoef, G.; Verdonck, L.F.; Ossenkoppele, G.J.; Sonneveld, P.; de Greef, G.E.; Löwenberg, B. \& Delwel, R. (2003) High EVI1 expression predicts poor survival in acute myeloid leukemia: a study of 319 de novo AML patients. Blood, Vol. 101, No. 3, (February), pp. 837-845, ISSN 0006-4971

Basecke, J.; Whelan, J.T.; Griesinger, F. \& Bertrand, F.E. (2006) The MLL partial tandem duplication in acute myeloid leukaemia. British Journal of Haematology, Vol. 135, No. 4, (November), pp. 438-449, ISSN 0007-1048

Becker, H.; Marcucci, G.; Maharry, K.; Radmacher, M.D.; Mrózek, K.; Margeson, D.; Whitman, S.P.; Wu, Y.Z.; Schwind, S.; Paschka, P.; Powell, B.L.; Carter, T.H.; Kolitz, J.E.; Wetzler, M.; Carroll, A.J.; Baer, M.R.; Caligiuri, M.A.; Larson, R.A. \& Bloomfield, C.D. (2010) Favorable prognostic impact of NPM1 mutations in older patients with cytogenetically normal de novo acute myeloid leukemia and associated gene- and microRNA-expression signatures: a Cancer and Leukemia Group B study. Journal of Clinical Oncology, Vol. 28, No. 4, (February), pp. 596-604, ISSN 0732-183X

Bianchini, M.; Ottaviani, E.; Grafone, T.;, Giannini, B.; Soverini, S.; Terragna, C.; Amabile, M.; Piccaluga, P.P.; Malagola, M.; Rondoni, M.; Bosi, C.; Baccarani, M. \& Martinelli, G. (2003) Rapid detection of Flt3 mutations in acute myeloid leukemia patients by denaturing HPLC. Clinical Chemistry, Vol. 49, No. 10, (October), pp. 1642-1650, ISSN 0009-9147

Boissel, N.; Nibourel, O.; Renneville, A.; Gardin, C.; Reman, O.; Contentin, N.; Bordessoule, D.; Pautas, C.; de Revel, T.; Quesnel, B.; Huchette, P.; Philippe, N.; Geffroy, S.; Terre, C.; Thomas, X.; Castaigne, S.; Dombret, H. \& Preudhomme, C. (2010) Prognostic impact of isocitrate dehydrogenase enzyme isoforms 1 and 2 mutations in acute myeloid leukemia: a study by the Acute Leukemia French Association group. Journal of Clinical Oncology, Vol. 28, No. 23, (August), pp. 3717-3723, ISSN 0732-183X

Bolli, N.; Nicoletti, I.; De Marco, M.F.; Bigerna, B.; Pucciarini, A.; Mannucci, R.; Martelli, M.P.; Liso, A.; Mecucci, C.; Fabbiano, F.; Martelli, M.F.; Henderson, B.R. \& Falini, B. (2007) Born to be exported: COOH-terminal nuclear export signals of different strength ensure cytoplasmic accumulation of nucleophosmin leukemic mutants. Cancer Research, Vol. 67, No. 13, (July), pp. 6230-623, ISSN 0008-5472

Borer, R.A.; Lehner, C.F.; H. M. Eppenberger, H.M. \& Nigg, E.A. (1989) Major nucleolar proteins shuttle between nucleus and cytoplasm. Cell, Vol. 56, No. 3, (February), pp. 379-390, ISSN 0092-8674

Bowen, D.T.; Frew, M.E.; Hills, R.; Gale, R.E.; Wheatley, K.; Groves, M.J.; Langabeer, S.E.; Kottaridis, P.D.; Moorman, A.V.; Burnett, A.K. \& Linch, D.C. (2005) RAS mutation in acute myeloid leukemia is associated with distinct cytogenetic subgroups but 
does not influence outcome in patients younger than 60 years. Blood, Vol. 106, No. 6, (September), pp. 2113-2119, ISSN 0006-4971

Bullinger, L. (2006) Gene expression profiling in acute myeloid leukemia. Haematologica, Vol. 91, No. 6, (June), pp. 733-738, ISSN 0390-6078

Bullinger, L. \& Armstrong, S.A. (2010) HELP for AML: methylation profiling opens new avenues. Cancer Cell, Vol. 17, No. 1, (January), pp. 1-3, ISSN 1535-6108

Bullinger, L.; Döhner, K.; Bair, E.; Fröhling, S.; Schlenk, R.F.; Tibshirani, R.; Döhner, H. \& Pollack, J.R. (2004) Use of gene-expression profiling to identify prognostic subclasses in adult acute myeloid leukemia. New England Journal of Medicine, Vol. 350, No. 16, (April), pp. 1605-1616, ISSN 0028-4793

Bullinger, L.; Döhner, K.; Kranz, R.; Stirner, C.; Fröhling, S.; Scholl, C.; Kim, Y.H.; Schlenk, R.F.; Tibshirani, R.; Döhner, H. \& Pollack, J.R. (2008) An FLT3 gene-expression signature predicts clinical outcome in normal karyotype AML. Blood, Vol. 111, No. 9, (May), pp. 4490-4495. ISSN 0006-4971

Bullinger, L. \& Valk, P.J. (2005) Gene expression profiling in acute myeloid leukemia. Journal of Clinical Oncology, Vol. 23, No. 26, (September), pp. 6296-6305, ISSN 0732-183X

Burnett, A.; Wetzler, M. \& Löwenberg, B. (2011) Therapeutic advances in acute myeloid leukemia. Journal of Clinical Oncology, Vol. 29, No. 5, (February), pp. 487-494, ISSN 0732-183X

Bustin, S.A.; Benes, V.; Nolan, T. \& Pfaffl, M.W. (2005) Quantitative real-time RT-PCR--a perspective. Journal of Molecular Endocrinology, Vol. 34, No. 3, (June), pp. 597-601, 0952-5041

Caligiuri, M.A.; Schichman, S.A.; Strout, M.P.; Mrózek, K.; Baer, M.R.; Frankel, S.R.; Barcos, M.; Herzig, G.P.; Croce, C.M. \& Bloomfield, C.D. (1994) Molecular rearrangement of the ALL-1 gene in acute myeloid leukemia without cytogenetic evidence of 11q23 chromosomal translocations. Cancer Research, Vol. 54, No. 2, (January), pp. 370-373, ISSN 0008-5472

Cazzola, M. (2010) IDH1 and IDH2 mutations in myeloid neoplasms-Novel paradigmsand cliunical implications. Haematologica, Vol. 95, No. 10, pp. 1623-1627, ISSN 0390-6078

Cilloni, D.; Renneville, A.; Hermitte, F.; Hills, R.K.; Daly, S.; Jovanovic, J.V.; Gottardi, E.; Fava, M.; Schnittger, S.; Weiss, T.; Izzo, B.; Nomdedeu, J.; van der Heijden, A.; van der Reijden, B.A.; Jansen, J.H.; van der Velden, V.H.; Ommen, H.; Preudhomme, C.; Saglio, G. \& Grimwade, D. (2009) Real-time quantitative polymerase chain reaction detection of minimal residual disease by standardized WT1 assay to enhance risk stratification in acute myeloid leukemia: a European LeukemiaNet study. Journal of Clinical Oncology, Vol. 27, No. 31, (November), pp. 5195-5201, ISSN 0732-183X

Chan, I.T.; Kutok, J.L.; Williams, I.R.; Cohen, S.; Kelly, L.; Shigematsu, H.; Johnson, L.; Akashi, K.; Tuveson, D.A.; Jacks, T. \& Gilliland, D.G. (2004) Conditional expression of oncogenic K-ras from its endogenous promoter induces a myeloproliferative disease. Journal of Clinical Investigation, Vol. 113, No. 4, (February), pp. 528-538, ISSN 0021-9738

Chan, W.Y.; Liu, Q.R; Borjigin, J.; Busch, H.; Rennert O.M. ; Tease, L.A. \& Chan, P.K. (1989) Characterization of the cDNA encoding human nucleophosmin and studies of its role in normal and abnormal growth. Biochemistry, Vol. 28, No. 3, (February), pp. 1033- 1039, ISSN 0006-2960 
Chen, C.C.; Gau, J.P.; You, J.Y.; Lee, K.D.; Yu, Y.B.; Lu, C.H.; Lin, J.T.; Lan, C.; Lo, W.H.; Liu, J.M. \& Yang, C.F. (2009) Prognostic significance of beta-catenin and topoisomerase IIalpha in de novo acute myeloid leukemia. American Journal of Hematology, Vol. 84, No. 2, (February), pp. 87-92, ISSN 0361-8609

Chou, W.C.; Hou, H.A.; Chen, C.Y.; Tang, J.L.; Yao, M.; Tsay, W.; Ko, B.S.; Wu, S.J.; Huang, S.Y.; Hsu, S.C.; Chen, Y.C.; Huang, Y.N.; Chang, Y.C.; Lee, F.Y.; Liu, M.C.; Liu, C.W.; Tseng, M.H.; Huang, C.F. \& Tien, H.F. (2010a) Distinct clinical and biologic characteristics in adult acute myeloid leukemia bearing the isocitrate dehydrogenase 1 mutation. Blood, Vol. 115, No. 14, (April), pp. 2749-2754, ISSN 0006-4971

Chou, W.C.; Huang, H.H.; Hou, H.A.; Chen, C.Y.; Tang, J.L.; Yao, M.; Tsay, W.; Ko, B.S.; Wu, S.J.; Huang, S.Y.; Hsu, S.C.; Chen, Y.C.; Huang, Y.N.; Chang, Y.C.; Lee, F.Y.; Liu, M.C.; Liu, C.W.; Tseng, M.H.; Huang, C.F. \& Tien, H.F. (2010b) Distinct clinical and biological features of de novo acute myeloid leukemia with additional sex comblike 1 (ASXL1) mutations. Blood, Vol. 116, No. 20, (November), pp. 4096-4094, ISSN 0006-4971

Chou, W.C.; Lei, W.C.; Ko, B.S.; Hou, H.A.; Chen, C.Y.; Tang, J.L.; Yao, M.; Tsay, W.; Wu, S.J.; Huang, S.Y.; Hsu, S.C.; Chen, Y.C.; Chang, Y.C.; Kuo, K.T.; Lee, F.Y.; Liu, M.C.; Liu, C.W.; Tseng, M.H.; Huang, C.F. \& Tien, H.F. (2011) The prognostic impact and stability of Isocitrate dehydrogenase 2 mutation in adult patients with acute myeloid leukemia. Leukemia, Vol. 25, No. 2, (February), pp. 246-253, ISSN 0887-6924

Colombo, E.; Bonetti, P.; Lazzerini Denchi, E.; Martinelli, P.; Zamponi, R.; Marine, J.C.; Helin, K.; Falini, B. \&. Pelicci, P.G. (2005) Nucleophosmin is required for DNA integrity and p19Arf protein stability. Molecular and Cellular Biology, Vol. 25, No. 20, (October), pp. 8874-8886, ISSN 0270- 7306

Colombo, E.; Marine, J.C.; Danovi, D.; Falini, B. \& Pelicci, P.G. (2002) Nucleophosmin regulates the stability and transcriptional activity of p53. Nature Cell Biology Vol. 4, No. 7, (July), pp. 529 - 533, ISSN 1465-7392

D'Alo', F.; Johansen, L.M.; Nelson, E.A.; Radomska, H.S.; Evans, E.K.; Zhang, P.; Nerlov, C. \& Tenen, D.G. (2003). The amino terminal and E2F interaction domains are critical for C/EBP alpha-mediated induction of granulopoietic development of hematopoietic cells. Blood, Vol. 102, No. 9, pp. 3163-3171, ISSN 0006-4971

Damm,F.; Heuser, M.; Morgan, M.; Yun, H.; Grosshennig, A.; Göhring, G.; Schlegelberger, B.; Döhner, K.; Ottmann, O.; Lübbert, M.; Heit, W.; Kanz, L.; Schlimok, G.; Raghavachar, A.; Fiedler, W.; Kirchner, H.; Döhner, H.; Heil, G.; Ganser, A. \& Krauter, J. (2010a) Single nucleotide polymorphism in the mutational hotspot of WT1 predicts a favorable outcome in patients with cytogenetically normal acute myeloid leukemia. Journal of Clinical Oncology, Vol. 28, No. 4 (February), 578-585, ISSN 0732-183X

Damm F, Heuser M, Morgan M, Wagner K, Görlich K, Grosshennig A, Hamwi I, Thol F, Surdziel E, Fiedler W, Lübbert M, Kanz L, Reuter C, Heil G, Delwel R, Löwenberg B, Valk PJ, Krauter J, Ganser A. (2011a) Integrative prognostic risk score in acute myeloid leukemia with normal karyotype. Blood, Mar 3. [Epub ahead of print], ISSN 0006-4971

Damm, F.; Lange, K.; Heuser, M.; Oberacker, T.; Morgan, M.; Wagner, K.; Krauter, J.; Schlegelberger, B.; Ganser, A. \& Göhring, G. (2010b) Phosphoinositide 
phospholipase Cbeta1 (PI-PLCbeta1) gene in myelodysplastic syndromes and cytogenetically normal acute myeloid leukemia: not a deletion, but increased PIPLCbeta1 expression is an independent prognostic factor. Journal of Clinical Oncology, Vol. 28, No. 22 (August), e384-387, ISSN 0732-183X

Damm, F.; Oberacker, T.; Thol, F.; Surdziel, E.; Wagner, K.; Chaturvedi, A.; Morgan, M.; Bomm, K.; Göhring, G.; Lübbert, M.; Kanz, L.; Fiedler, W.; Schlegelberger, B.; Heil, G.; Schlenk, R.F.; Döhner, K.; Döhner, H.; Krauter, J.; Ganser, A. \& Heuser, M. (2011b)Prognostic importance of histone methyltransferase MLL5 expression in acute myeloid leukemia. Journal of Clinical Oncology, Vol. 29, No. 6 (February), pp. 682-689, ISSN 0732-183X

Dang, L.; Jin, S. \& Su, S.M. (2010) IDH mutations in glioma and acute myeloid leukemia. Trends in Molecular Medicine, Vol. 16, No. 9, (September), pp. 387-397, ISSN 14714914

De Braekeleer, M.; Morel, F.; Le Bris, M.J.; Herry, A. \& Douet-Guilbert, N. (2005) The MLL gene and translocations involving chromosomal band 11q23 in acute leukemia. Anticancer Research, Vol. 25, No. 3B, (May-June), pp. 1931-1944, ISSN 0250-7005

De Jonge, H.J.M.; Valk, P.J.; Veeger, N.J.; ter Elst, A.; den Boer, M.L.; Cloos, J.; de Haas, V.; van den Heuvel-Eibrink, M.M.; Kaspers. G.J.; Zwaan, C.M.; Kamps, W.A.; Löwenberg, B. \& de Bont, E.S. (2010) High VEGFC expression is associated with unique gene expression profiles and predicts adverse prognosis in pediatric and adult acute myeloid leukemia. Blood, Vol. 116, No. 10, pp. 1747-1754, ISSN 00064971

Del Poeta, G.; Ammatuna, E.; Lavorgna, S.; Capelli, G.; Zaza, S.; Luciano, F.; Ottone, T.; Del Principe, M.I.; Buccisano, F.; Maurillo, L.; Panetta, P.; de Fabritiis, P.; Stasi, R.; Venditti, A.; Amadori, S. \& Lo Coco, F. (2010) The genotype nucleophosmin mutated and FLT3-ITD negative is characterized by high bax/bcl-2 ratio and favourable outcome in acute myeloid leukaemia. British Journal of Haematology, Vol. 149, No. 3, (May), pp. 383-387, ISSN 0007-1048

Damiani, D.; Tiribelli, M.; Michelutti, A.; Geromin, A.; Cavallin, M.; Fabbro, D.; Pianta, A.;Malagola, M.; Damante, G.; Russo, D. \& Fanin, R. (2010) Fludarabine-based induction therapy does not overcome the negative effect of ABCG2 (BCRP) overexpression in adult acute myeloid leukemia patients. Leukemia Research, Vol. 34, No. 7, (July), pp. 942-945,ISSN 0145-2126

Döhner, K. \& Döhner, H. (2008) Molecular characterization of acute myeloid leukemia. Haematologica, Vol. 93, No. 7, (July), pp. 976-982, ISSN 0390-6078

Döhner, H.; Estey, E.H.; Amadori, S.; Appelbaum, F.R.; Büchner, T.; Burnett, A.K.; Dombret, H.; Fenaux, P.; Grimwade, D.; Larson, R.A., Lo-Coco, F.; Naoe, T.; Niederwieser, D.; Ossenkoppele, G.J.; Sanz, M.A.; Sierra, J.; Tallman, M.S.; Löwenberg, B.; Bloomfield, C.D. \& European LeukemiaNet (2010) Diagnosis and management of acute myeloid leukemia in adults: recommendations from an international expert panel, on behalf of the European LeukemiaNet. Blood, Vol. 115, No. 3, (January), pp. 453-474, , ISSN 0006-4971

Döhner, K.; Tobis, K.; Ulrich, R.; Fröhling, S.; Benner, A.; Schlenk, R.F. \& Döhner, H. (2002) Prognostic significance of partial tandem duplications of the MLL gene in adult patients 16 to 60 years old with acute myeloid leukemia and normal cytogenetics: a 
study of the Acute Myeloid Leukemia Study Group Ulm. Journal of Clinical Oncology, Vol. 20, No. 15, (August), pp. 3254-3261, ISSN 0732-183X

Dorrance, A.M.; Liu, S.; Yuan, W.; Becknell, B.; Arnoczky, K.J.; Guimond, M.; Strout, M.P.; Feng, L.; Nakamura, T.;Yu, L.; Rush, L.J.; Weinstein, M.; Leone, G.; Wu, L.; Ferketich, A.; Whitman, S.P.; Marcucci, G. \& Caligiuri, M.A. (2006) Mll partial tandem duplication induces aberrant Hox expression in vivo via specific epigenetic alterations. Journal of Clinical Investigation, Vol. 116, No. 10, (October), pp. 27072716, ISSN 0021-9738

Dvorakova, D.; Racil, Z.; Jeziskova, I.; Palasek, I.; Protivankova, M.; Lengerova, M.; Razga, F. \& Mayer, J. (2010) Monitoring of minimal residual disease in acute myeloid leukemia with frequent and rare patient-specific NPM1 mutations. American Journal of Hematology, Vol. 85, No. 12, (December), pp. 926-929, ISSN 0361-8609

Dufour, A.; Schneider, F.; Metzeler, K.H.; Hoster, E.; Schneider, S.; Zellmeier, E.; Benthaus, T.; Sauerland, M.C.; Berdel, W.E.; Büchner, T.; Wörmann, B.; Braess, J.; Hiddemann, W.; Bohlander, S.K. \& Spiekermann, K. (2010) Acute myeloid leukemia with biallelic CEBPA gene mutations and normal karyotype represents a distinct genetic entity associated with a favorable clinical outcome. Journal of Clinical Oncology, Vol. 28, No. 4, (February), pp. 570-577, ISSN 0732-183X

Enomoto, T.; Lindström, M.S.; Jin, A.; Ke, H. \& Zhang, Y. (2006) Essential role of the B23/NPM core domain in regulatingARF binding and B23 stability. Journal of Biological Chemistry, Vol. 281, No. 27, (May), pp. 18463-18472, ISSN 0021-9258

Epping, M.T.; Wang, L.; Edel, M.J.; Carlée, L.; Hernandez, M. \& Bernards, R. (2005) The human tumor antigen PRAME is a dominant repressor of retinoic acid receptor signaling. Cell, Vol. 122, No. 6, (September), pp. 835-847, ISSN 0092-8674

Falini, B. (2010b) Acute myeloid leukemia with mutated nucleophosmin (NPM1): molecular,pathological, and clinical features. Cancer Treatment and Research, Vol. 145, pp. 149-168, ISSN 0927-3042

Falini, B.; Bolli, N.; Liso, A.; Martelli, M.P.; Mannucci, R.; Pileri, S. \& Nicoletti, I. (2009) Altered nucleophosmin transport in acute myeloid leukaemia with mutated NPM1: molecular basis and clinical implications. Leukemia, Vol. 23, No.10, (October),pp. 1731-1743, ISSN 0887-6924

Falini, B.; Bolli, N.; Shan, J.; Martelli, M.P.; Liso, A.; Pucciarini, A.; Bigerna, B.; Pasqualucci, L.; Mannucci, R.; Rosati, R.; Gorello, P.; Diverio, D.; Roti, G.; Tiacci, E.; Cazzaniga, G.; Biondi, A.; Schnittger, S.; Haferlach, T.; Hiddemann, W.; Martelli, M.F.; Gu, W.; Mecucci, C. \& Nicoletti, I. (2006b) Both carboxy-terminus NES motif and mutated tryptophan(s) are crucial for aberrant nuclear export of nucleophosmin leukemic mutants in NPMc+ AML. Blood, Vol. 107, No. 11, (June), pp. 4514-4523, ISSN 00064971

Falini, B.; Mecucci, C.; Tiacci, E.; Alcalay, M.; Rosati, R.; Pasqualucci, L.; La Starza, R.; Diverio, D.; Colombo, E.; Santucci, A.; Bigerna, B.; Pacini, R.; Pucciarini, A.; Liso, A.; Vignetti, M.; Fazi, P.; Meani, N.; Pettirossi, V.; Saglio, G.; Mandelli, F.; Lo-Coco, F.; Pelicci, P.G.; Martelli, M.F. \& GIMEMA Acute Leukemia Working Party. (2005) Cytoplasmic nucleophosmin in acute myelogenous leukemia with a normal karyotype. The New England Journal of Medicine, Vol. 352, No. 3, (January), pp. 254266, ISSN 0028-4793 
Falini, B.; Martelli, M.P.; Bolli, N.;, Bonasso, R.; Ghia, E.; Pallotta, M.T.; Diverio, D.; Nicoletti, I.; Pacini, R.; Tabarrini, A.; Galletti, B.V.; Mannucci, R.; Roti, G.; Rosati, R.; Specchia, G.; Liso, A.; Tiacci, E.; Alcalay, M.; Luzi, L.; Volorio, S.; Bernard, L.; Guarini, A.; Amadori, S.; Mandelli, F.; Pane, F.; Lo-Coco, F.; Saglio, G.; Pelicci, P.G.; Martelli, M.F. \& Mecucci, C. (2006) Immunohistochemistry predicts nucleophosmin (NPM) mutations in acute myeloid leukemia. Blood, Vol. 108, No. 6, (September), pp. 19992005, ISSN 0006-4971

Falini, B.; Martelli, M.P.; Bolli, N.; Sportoletti, P.; Liso, A.; Tiacci, E. \& Haferlach, T. (2011) Acute myeloid leukemia with mutated nucleophosmin (NPM1): is it a distinct entity? Blood, Vol. 117, No. 4, (January), pp. 1109-1120, ISSN 0006-4971

Falini, B.; Martelli, M.P.; Pileri, S.A. \& Mecucci, C. (2010a) Molecular and alternative methods for diagnosis of acute myeloid leukemia with mutated NPM1: flexibility may help. Haematologica, Vol. 95, No. 4, (April), pp. 529-534, ISSN 0390-6078

Figueroa, M.E.; Abdel-Wahab, O.; Lu, C.; Ward, P.S.; Patel, J.; Shih, A.; Li, Y.; Bhagwat, N.; Vasanthakumar, A.; Fernandez, H.F.; Tallman, M.S.; Sun, Z.; Wolniak, K.; Peeters, J.K.; Liu, W.; Choe, S.E.; Fantin, V.R.; Paietta, E.; Löwenberg, B.; Licht, J.D.; Godley, L.A.; Delwel, R.; Valk, P.J.; Thompson, C.B.; Levine, R.L. \& Melnick, A. (2010) Leukemic IDH1 and IDH2 mutations result in a hypermethylation phenotype, disrupt TET2 function, and impair hematopoietic differentiation. Cancer Cell, Vol. 18, No. 6, (December), pp. 553-567, ISSN 1535-6108

Figueroa, M.E.; Lugthart, S.; Li, Y.; Erpelinck-Verschueren, C.; Deng, X.; Christos, P.J.; Schifano, E.; Booth, J.; van Putten, W.; Skrabanek, L.; Campagne, F.; Mazumdar, M.; Greally, J.M.; Valk, P.J.; Löwenberg, B.; Delwel, R. \& Melnick, A. (2010) DNA methylation signatures identify biologically distinct subtypes in acute myeloid leukemia. Cancer Cell, Vol. 17, No. 1, (January), pp. 13-17, ISSN 1535-6108

Flodby, P.; Barlow, C.; Kylefjord, H.; Ahrlund-Richter, L. \& Xanthopoulos, K.G. (1996) Increased hepatic cell proliferation and lung abnormalities in mice deficient in CCAAT/enhancer binding protein alpha. Journal of Biological Chemistry, Vol. 271, No. 40, (October), pp. 24753-24760, ISSN 0021-9258

Frayling, I.M. (2002) Methods of molecular analysis: mutation detection in solid tumours. Molecular Pathology, Vol. 55, No. 2, (April), ISSN 1366-8714

Frehlick, L.J.; Eirín-López, J.M. \& Ausió, J. (2007). New insights into the nucleophosmin/ nucleoplasmin family of nuclear chaperones. BioEssays, Vol. 29, No.1, (January), pp. 49-59, ISSN 1521-1878

Friedman, A.D. (2007) C/EBPalpha induces PU.1 and interacts with AP-1 and NF-kappaB to regulate myeloid development. Blood Cells, Moecules and Diseases, Vol. 39, No. 3, (November-December), pp. 340-343, ISSN 1079-9796

Fröhling, S.; Schlenk, R.F.; Breitruck, J.; Benner, A.; Kreitmeier, S.; Tobis, K.; Döhner, H. \& Döhner, K. (2002) AML Study Group Ulm. Acute myeloid leukemia. Prognostic significance of activating FLT3 mutations in younger adults (16 to 60 years) with acute myeloid leukemia and normal cytogenetics: a study of the AML Study Group Ulm. Blood, Vol. 100, No. 13, (December), pp. 4372-4380, ISSN 0006-4971

Fröhling, S.; Schlenk, R.F.; Stolze, I.; Bihlmayr, J.; Benner, A.; Kreitmeier, S.; Tobis, K.; Döhner, H. \& Döhner, K. (2004) CEBPA mutations in younger adults with acute myeloid leukemia and normal cytogenetics: prognostic relevance and analysis of 
cooperating mutations. Journal of Clinical Oncology, Vol. 22, No. 4, (February), pp. 624-633, ISSN 0732-183X

Fuchs, O. (2007) Growth-inhibiting activity of transcription factor C/EBPalpha, its role in haematopoiesis and its tumour suppressor or oncogenic properties in leukaemias. Folia Biologica (Praha), Vol. 53, No. 3, pp. 97-108, ISSN 0015-5500

Fuchs, O.; Provaznikova, D.; Kocova, M.; Kostecka, A.; Cvekova, P.; Neuwirtova, R.; Kobylka, P.; Cermak, J.; Brezinova, J.; Schwarz, J.; Markova, J.; Salaj, P.; Klamova, H.; Maaloufova, J.; Lemez, P.; Novakova, L. \& Benesova, K. (2008) CEBPA polymorphisms and mutations in patients with acute myeloid leukemia, myelodysplastic syndrome, multiple myeloma and non-Hodgkin's lymphoma. Blood Cells, Moecules and Diseases, Vol. 40, No. 3, (May-June), pp. 401-405, ISSN10799796

Fuchs, O.; Kostecka, A.; Provaznikova, D.; Krasna, B.; Brezinova, J.; Filkukova, J.; Kotlin, R.; Kouba, M.; Kobylka, P.; Neuwirtova, R.; Jonasova, A.; Caniga, M.; Schwarz, J.; Markova, J.; Maaloufova, J.; Sponerova, D.; Novakova, L. \& Cermak, J. (2009) Nature of frequent deletions in CEBPA. Blood Cells, Molecules and Diseases, Vol. 43, No. 3 (November-December), pp. 260-263, ISSN1079-9796

Gaidzik, V. \& Döhner , K. (2008) Prognostic implications of gene mutations in acute myeloid leukemia with normal cytogenetics. Seminars in Oncology, Vol. 35, No. 4, (August), pp. 346-355, ISSN 0093-7754

Gaidzik, V.I.; Schlenk, R.F.; Moschny, S.; Becker, A.; Bullinger, L.; Corbacioglu, A.; Krauter, J.;Schlegelberger, B.; Ganser, A.; Döhner, H.; Döhner, K. \& German-Austrian AML Study Group. Prognostic impact of WT1 mutations in cytogenetically normal acute myeloid leukemia: a study of the German-Austrian AML Study Group. Blood, Vol. 113, No. 19, (May), pp. 4505-11, ISSN 0006-4971

Gale, R.E.; Green, C.; Allen, C.; Mead, A.J.; Burnett, A.K.; Hills, R.K.; Linch, D.C. \& Medical Research Council Adult Leukaemia Working Party (2008) The impact of FLT3 internal tandem duplication mutant level, number, size, and interaction with NPM1 mutations in a large cohort of young adult patients with acute myeloid leukemia. Blood, Vol. 111, No. 5,(March), pp. 2776-2784, ISSN 0006-4971

Garzon, R.; Garofalo, M.; Martelli, M.P.; Briesewitz, R.; Wang, L.; Fernandez-Cymering, C.; Volinia, S.; Liu, C.G.; Schnittger, S.; Haferlach, T.; Liso, A.; Diverio, D.; Mancini, M.; Meloni, G.; Foa, R.; Martelli, M.F.; Mecucci, C.; Croce, C.M. \& Falini, B. (2008) Distinctive microRNA signature of acute myeloid leukemia bearing cytoplasmic mutated nucleophosmin. The Proceedings of the National Academy of Sciences of the USA, Vol. 105, No. 10, pp. 3945-3950, ISSN 0027-8424

Geisbrecht, B.V., Gould, S.J.(1999) The human PICD gene encodes a cytoplasmic and peroxisomal NADP(+)-dependent isocitrate dehydrogenase. Journal of Biological Chemistry, Vol. 274, No. 43, (October), pp. 30527-30533, ISSN 0021-9258

Gianfaldoni, G.; Mannelli, F.; Ponziani, V.; Longo, G.; Bencini, S.; Bosi, A. \& Vannucchi, A.M. (2010) Early reduction of WT1 transcripts during induction chemotherapy predicts for longer disease free and overall survival in acute myeloid leukemia. Haematologica, Vol. 95, No. 5, (May), pp. 833-836, ISSN 0390-6078

Gilliland, D.G. \& Griffin, J.D. (2002) The roles of FLT3 in hematopoiesis and leukemia. Blood, Vol. 100, No. 5, (September), pp. 1532-1542, ISSN: 0006-4971 
Golub,T.; Slonim, D.K.; Tamayo, P.; Huard, C., Gaasenbeek M, Mesirov JP, Coller H, Loh ML, Downing JR, Caligiuri MA, Bloomfield CD, Lander ES. (1999) Molecular classification of cancer: class discovery and class prediction by gene expression monitoring. Science, Vol. 286, No. 5439, (October), pp.531-537, ISSN 0036-8075

Gombart, A.F.; Hofmann, W.K.; Kawano, S.; Takeuchi, S.; Krug, U.; Kwok, S.H.; Larsen, R.J.; Asou, H.; Miller, C.W.; Hoelzer, D. \& Koeffler, H.P. (2002) Mutations in the gene encoding the transcription factor CCAAT/enhancer binding protein alpha in myelodysplastic syndromes and acute myeloid leukemias. Blood, Vol. 99, No. 4, (February), pp. 1332-1340, ISSN 0006-4971

Green, C.L.; Evans, C.M.; Hills, R.K.; Burnett, A.K.; Linch, D.C. \& Gale, R.E. (2010) The prognostic significance of IDH1 mutations in younger adult patients with acute myeloid leukemia is dependent on FLT3/ITD status. Blood, Vol. 116, Vol. 15, (October), pp. 2779-2782, ISSN 0006-4971

Greif, P.A.; Eck, S.H.; Konstandin, N.P.; Benet-Pagès, A.; Ksienzyk, B.; Dufour, A.; Vetter, A.T.; Popp, H.D.; Lorenz-Depiereux, B.; Meitinger, T.; Bohlander, S.K. \& Strom, T.M. (2011) Identification of recurring tumor-specific somatic mutations in acute myeloid leukemia by transcriptome sequencing. Leukemia, Feb 22. [Epub ahead of print], ISSN 0887-6924

Greiner, J.; Bullinger, L.; Guinn, B.A.; Döhner, H. \& Schmitt, M. (2008) Leukemia-associated antigens are critical for the proliferation of acute myeloid leukemia cells. Clinical Cancer Research, Vol. 14, No. 22, (November), pp. 7161-7166, ISSN 1078-0432

Grisendi, S.; Mecucci, C.; Falini, B. \&. Pandolfi, P.P. (2006) Nucleophosmin and cancer. Nature Reviews Cancer, Vol. 6, No. 7, (July), pp. 493-505, ISSN 1474-175X

Gröschel, S.; Lugthart, S.; Schlenk, R.F.; Valk, P.J.; Eiwen, K.; Goudswaard, C.; van Putten, W.J.; Kayser, S.; Verdonck, L.F.; Lübbert, M.; Ossenkoppele, G.J.; Germing, U.; Schmidt-Wolf, I.; Schlegelberger, B.; Krauter, J.; Ganser, A.; Döhner, H.; Löwenberg, B.; Döhner, K. \& Delwel, R. (2010) High EVI1 expression predicts outcome in younger adult patients with acute myeloid leukemia and is associated with distinct cytogenetic abnormalities. Journal of Clinical Oncology, Vol. 28, No. 12, (April), pp. 2107-2107, ISSN 0732-183X

Gross, S.; Cairns, R.A.; Minden, M.D.; Driggers, E.M.; Bittinger, M.A.; Jang, H.G.; Sasaki, M.; Jin, S.; Schenkein, D.P.; Su, S.M.; Dang, L.; Fantin, V.R. \& Mak, T.W. (2010) Cancerassociated metabolite 2-hydroxyglutarate accumulates in acute myelogenous leukemia with isocitrate dehydrogenase 1 and 2 mutations. Journal of Experimental Medicine, Vol. 207, No. 2, (February), pp. 339-344, ISSN 0022-1007

Grosveld, G.C. (2007) MN1, a novel player in human AML. Blood Cells Molecules and Diseases, Vol. 39, No. 3, November- December), pp. 336-339, ISSN 1079-9796

$\mathrm{Gu}$, Y.; Jasti, A.C.; Jansen, M. \& Siefring, J.E. RhoH, a hematopoietic-specific Rho GTPase, regulates proliferation, survival, migration, and engraftment of hematopoietic progenitor cells. Blood, Vol. 105, Vol. 4, (February), pp. 1467-1475, ISSN 0006-4971

Gündogdu, M.S.; Liu, H.; Metzdorf, D.; Hildebrand, D.; Aigner, M.; Aktories, K.; Heeg, K. \& Kubatzky, K.F. (2010) The haematopoietic GTPase RhoH modulates IL3 signalling through regulation of STAT activity and IL3 receptor expression. Molecular Cancer, Vol. 25, No. 9, (August), p. 225, ISSN 1476-4598

Haber, D.A.; Buckler, A.J.; Glaser, T.; Call, K.M.; Pelletier, J.; Sohn, R.L.; Douglass, E.C. \& Housman, D.E. (1990) An internal deletion within an 11 p13 zinc finger gene 
contributes to the development of Wilms' tumor. Cell, Vol. 61, No. 7, (June), pp. 1257-1269, ISSN 0092-8674

Hackanson, B.; Bennett, K.L.; Brena, R.M.; Jiang, J.; Claus, R.; Chen, S.S.; Blagitko-Dorfs, N.; Maharry, K.; Whitman, S.P.; Schmittgen, T.D.; Lübbert, M.; Marcucci, G.; Bloomfield, C.D. \& Plass, C. (2008) Epigenetic modification of CCAAT/enhancer binding protein alpha expression in acute myeloid leukemia. Cancer Research, Vol. 68, No. 9, (May), pp. 3142-3151, ISSN 0008-5472

Harada, Y. \& Harada, H. (2009) Molecular pathways mediating MDS/AML with focus on AML1/RUNX1 point mutations. Journal of Cellular Physiology, Vol. 220, No. 1, (July), pp. 16-20, ISSN 0021-9541

Heesch. S.; Schlee, C.; Neumann, M.; Stroux, A.; Kühnl, A.; Schwartz, S.; Haferlach, T.; Goekbuget, N.; Hoelzer, D.;, Thiel, E.; Hofmann, W.K. \& Baldus, C.D. (2010) BAALC-associated gene expression profiles define IGFBP7 as a novel molecular marker in acute leukemia. Leukemia, Vol. 24, No. 8, (August), pp. 1429-1436, ISSN 0887-6924

Herrera, J. E.; Savkur, R. \& Olson, M. O. (1995) The ribonuclease activity of nucleolar protein B23. Nucleic Acids Research, Vol. 23, No. 19, (October), pp. 3974-3979, ISSN 03051048

Heuser, M.; Argiropoulos, B.; Kuchenbauer, F.; Yung, E.; Piper, J.; Fung, S.; Schlenk, R.F.; Dohner, K.; Hinrichsen, T.; Rudolph, C.; Schambach, A.; Baum, C.; Schlegelberger, B.; Dohner, H.; Ganser, A. \& Humphries, R.K. (2007) MN1 overexpression induces acute myeloid leukemia in mice and predicts ATRA resistance in patients with AML. Blood, Vol. 110, No. 5, (September), pp. 1639-1647, ISSN 0006-4971

Heuser, M.; Beutel, G.; Krauter, J.; Döhner, K.; von Neuhoff, N.; Schlegelberger, B. \& Ganser, A. (2006) High meningioma 1 (MN1) expression as a predictor for poor outcome in acute myeloid leukemia with normal cytogenetics. Blood, Vol. 108, No. 12, (December), pp. 3898-3905, ISSN 0006-4971

Hisaoka, M.; Ueshima, S.; Murano, K.; Nagata, K. \& Okuwaki, M. (2010) Regulation of nucleolar chromatin by B23/nucleophosmin jointly depends upon its RNA binding activity and transcription factor UBF. Molecular and Cellular Biology, Vol. 30, No. 20, (October), pp. 4952-4964, ISSN 0270- 7306

Hou, H.A.; Chou, W.C.; Lin, L.I.; Tang, J.L.; Tseng, M.H.; Huang, C.F.; Yao, M.; Chen, C.Y.; Tsay, W. \& Tien, H.F. (2008) Expression of angiopoietins and vascular endothelial growth factors and their clinical significance in acute myeloid leukemia. Leukemia Research, Vol. 32, No. 6, (June), pp. 904-912, ISSN0145-2126

Hou, H.A.; Huang, T.C.; Lin, L.I.; Liu, C.Y.; Chen, C.Y.; Chou, W.C.; Tang, J.L.; Tseng, M.H.; Huang, C.F.; Chiang, Y.C.; Lee, F.Y.; Liu, M.C.; Yao, M.; Huang, S.Y.; Ko, B.S.; Hsu, S.C.; Wu, S.J.; Tsay, W.; Chen, Y.C. \& Tien, H.F. (2010) WT1 mutation in 470 adult patients with acute myeloid leukemia: stability during disease evolution and implication of its incorporation into a survival scoring system. Blood, Vol. 115, No. 25, (June), pp. 5222-5231, ISSN 0006-4971

Hou, H.A.; Lin, L.I.; Chen, C.Y. \& Tien, H.F. (2009) Reply to 'Heterogeneity within AML with CEBPA mutations; only CEBPA double mutations, but not single CEBPA mutations are associated with favorable prognosis'. British Journal of Cancer, Vol. 101, No. 4, (August), pp. 738-740, ISSN 0007-0920 
Huh, H.J.; Park, C.J.; Jang, S.; Seo, E.J.; Chi, H.S.; Lee, J.H.; Lee, K.H.; Seo, J.J.; Moon, H.N. \& Ghim T. (2006) Prognostic significance of multidrug resistance gene 1 (MDR1), multidrug resistance-related protein (MRP) and lung resistance protein (LRP) mRNA expression in acute leukemia. Journal of Korean Medical Science, Vol. 21, No. 2, (April), pp. 253-258, ISSN 1011-8934

Iwasaki, T.; Katsumi, A.; Kiyoi, H.; Tanizaki, R.; Ishikawa, Y.; Ozeki, K.; Kobayashi, M.; Abe, A.; Matsushita, T.; Watanabe, T.; Amano, M.; Kojima, T.; Kaibuchi, K. \& Naoe, T. (2008) Prognostic implication and biological roles of $\mathrm{RhoH}$ in acute myeloid leukaemia. European Journal of Haematology, Vol. 81, No. 6, (December), pp. 454-460, ISSN 0902-4441

Jaeger, U. \& Kainz. B. (2003) Monitoring minimal residual disease in AML: the right time for real time. Annals of Hematology, Vol. 82, No. 3, (March), pp.139-147, ISSN 0939-5555

Juliusson, G.; Antunovic, P.; Derolf, A.; Lehmann, S.; Möllgård, L.; Stockelberg, D.; Tidefelt, U.; Wahlin, A. \& Höglund, M. (2009) Age and acute myeloid leukemia: real world data on decision to treat and outcomes from the Swedish Acute Leukemia Registry. Blood, Vol. 113, No. 18, (April), pp. 4179-4187, ISSN 0006-4971

Kato, N.; Kitaura, J.; Doki, N.; Komeno, Y.; Watanabe-Okochi, N.; Togami, K.; Nakahara, F.; Oki, T.; Enomoto, Y.; Fukuchi, Y.; Nakajima, H.; Harada, Y.; Harada, H. \& Kitamura, T. (2011) Two types of C/EBPa mutations play distinct but collaborative roles in leukemogenesis: lessons from clinical data and BMT models. Blood, Vol. 117, No. 1, (January), pp. 221-233, ISSN 0006-4971

Keeshan, K.; Santilli, G.; Corradini, F.; Perrotti, D. \& Calabretta, B. (2003) Transcription activation functionof $\mathrm{C} / \mathrm{EBPa}$ is required for induction of granulocyte differentiation. Blood, Vol. 102, No. 4, (August), pp. 1267-1275, ISSN 0006-4971

Kern, W.; Schoch, C.; Haferlach, T. \& Schnittger, S. (2005) Monitoring of minimal residual disease in acute myeloid leukemia. Critical Reviews in Oncology / Hematology, Vol. 56, No. 2, (November), pp. 283-309, ISSN 1040-8428

Kindler, T.; Lipka, D.B. \& Fischer, T. (2010) FLT3 as a therapeutic target in AML: still challenging after all these years. Blood, Vol. 116, No. 24, (December), pp. 5089-5102, ISSN 0006-4971

King-Underwood, L.; Renshaw, J. \& Pritchard-Jones, K. (1996) Mutations in the Wilms' tumor gene WT1 in leukemias. Blood, Vol. 87, No. 6, (March), pp. 2171-2179, ISSN 0006-4971

Kohlmann, A.; Bullinger, L.; Thiede, C.; Schaich, M.; Schnittger, S.; Döhner, K.; Dugas, M.; Klein, H.U.; Döhner, H.; Ehninger, G. \& Haferlach, T. (2010) Gene expression profiling in AML with normal karyotype can predict mutations for molecular markers and allows novel insights into perturbed biological pathways. Leukemia, Vol. 24, No. 6, (June), pp. 1216-1220, ISSN 0887-6924

Koike, A.; Nishikawa, H.;, Wu, W.; Okada, Y.; Venkitaraman, A.R. \& Ohta, T. (2010) Recruitment of phosphorylated NPM1 to sites of DNA damage through RNF8dependent ubiquitin conjugates. Cancer Research, Vol. 70, No. 17 (September), pp. 6746-6756, ISSN 0008-5472

Konoplev, S.; Rassidakis, G.Z.; Estey, E.; Kantarjian, H.; Liakou, C.I.; Huang, X.;, Xiao, L.; Andreeff, M.; Konopleva, M. \& Medeiros, L.J. (2007) Overexpression of CXCR4 predicts adverse overall and event-free survival in patients with unmutated FLT3 
acute myeloid leukemia with normal karyotype. Cancer, Vol. 109, No. 6, (March), pp. 1152-1156, ISSN 1097-0142

Kornblau, S.M., Singh, N.; Qiu, Y.; Chen, W.; Zhang, N. \& Coombes, K.R. (2010) Highly phosphorylated FOXO3A is an adverse prognostic factor in acute myeloid leukemia. Clinical Cancer Research, Vol.16, No. 6, (March), pp. 1865-1874, ISSN 10780432

Kosaki, K.; Udaka, T. \& Okuyama, T. (2005) DHPLC in clinical molecular diagnostic services. Molecular Genetics and Metabolism, Vol. 86, No. 1-2, (September-October), pp. 117-123, ISSN 1096-7192

Kutach, L.S., Bolshakov, S., Ananthaswamy, H.N. (1999) Detection of mutations and polymorphisms in the p53 tumor suppressor gene by single-strand conformation polymorphism analysis. Electrophoresis, Vol. 20, No. 6, (June), pp. 1204-1210, ISSN 0173-0835

Lange, T.; Hubmann, M.; Burkhardt, R.; Franke, G.N.; Cross, M.; Scholz, M.; Leiblein, S.; AlAli, H.K.; Edelmann, J.; Thiery, J. \& Niederwieser, D. (2011) Monitoring of WT1 expression in $\mathrm{PB}$ and $\mathrm{CD} 34(+)$ donor chimerism of $\mathrm{BM}$ predicts early relapse in AML and MDS patients after hematopoietic cell transplantation with reducedintensity conditioning. Leukemia, Vol. 25, No. 3, (March), pp. 498-505, ISSN 08876924

Langer, C.; Marcucci, G.; Holland, K.B.; Radmacher, M.D.; Maharry, K.; Paschka, P.; Whitman, S.P.; Mrózek, K.; Baldus, C.D.; Vij, R.; Powell, B.L.; Carroll, A.J.; Kolitz, J.E.; Caligiuri, M.A.; Larson, R.A. \& Bloomfield, C.D. (2009) Prognostic importance of MN1 transcript levels, and biologic insights from MN1-associated gene and microRNA expression signatures in cytogenetically normal acute myeloid leukemia: a cancer and leukemia group B study. Journal of Clinical Oncology, Vol. 27, No. 19, (July), pp. 3198-3204, ISSN 0732-183X

Langer, C.; Radmacher, M.D.; Ruppert, A.S.; Whitman, S.P.; Paschka, P.; Mrózek, K.; Baldus, C.D.; Vukosavljevic, T.; Liu, C.G.; Ross, M.E.; Powell, B.L.; de la Chapelle, A.; Kolitz, J.E.; Larson, R.A.; Marcucci, G. \& Bloomfield, C.D. Cancer and Leukemia Group B (CALGB) (2008) High BAALC expression associates with other molecular prognostic markers, poor outcome, and a distinct gene-expression signature in cytogenetically normal patients younger than 60 years with acute myeloid leukemia: a Cancer and Leukemia Group B (CALGB) study. Blood, Vol. 111, No. 11, (June), pp. 5371-5379, ISSN 0006-4971

Lee, C.Y.; Tien, H.F.; Hu, C.Y.; Chou, W.C. \& Lin, L.I. (2007) Marrow angiogenesisassociated factors as prognostic biomarkers in patients with acute myelogenous leukaemia. British Journal of Cancer, Vol. 97, No. 7, (October), pp. 877-882, ISSN

Leith, C.P.; Kopecky, K.J.; Chen, I.M.; Eijdems, L.; Slovak, M.L.; McConnell, T.S.; Head, D.R.; Weick, J.; Grever, M.R.; Appelbaum, F.R. \& Willman, C.L. (1999) Frequency and clinical significance of the expression of the multidrug resistance proteins MDR1/P-glycoprotein, MRP1, and LRP in acute myeloid leukemia: a Southwest Oncology Group Study. Blood, Vol. 94, No. 3, (August), pp. 1086-1099, ISSN 00064971

Leong, S.M.; Tan, B.X.; Bte Ahmad, B.; Yan, T.; Chee, L.Y.; Ang, S.T.; Tay, K.G.; Koh, L.P.; Yeoh, A.E.; Koay, E.S.; Mok, Y.K. \& Lim, T.M. (2010) Mutant nucleophosmin 
deregulates cell death and myeloid differentiation through excessive caspase- 6 and -8 inhibition. Blood, Vol. 116, No. 17, (October), pp. 3286-3296, ISSN 0006-4971

Ley, T.J.; Ding, L.; Walter, M.J.; McLellan, M.D.; Lamprecht, T.; Larson, D.E.; Kandoth, C.; Payton, J.E.; Baty, J.; Welch, J.; Harris, C.C.; Lichti, C.F.; Townsend, R.R.; Fulton, R.S.; Dooling, D.J.; Koboldt, D.C.; Schmidt, H.; Zhang, Q.; Osborne, J.R.; Lin, L.; O'Laughlin, M.; McMichael, J.F.; Delehaunty, K.D.; McGrath, S.D.; Fulton, L.A.; Magrini, V.J.; Vickery, T.L.; Hundal, J.; Cook, L.L.; Conyers, J.J.; Swift, G.W.; Reed, J.P.; Alldredge, P.A.; Wylie, T.; Walker, J.; Kalicki, J.; Watson, M.A.; Heath, S.; Shannon, W.D.; Varghese, N.; Nagarajan, R.; Westervelt, P.; Tomasson, M.H.; Link, D.C.; Graubert, T.A.; DiPersio, J.F.; Mardis, E.R. \& Wilson, R.K. (2010) DNMT3A mutations in acute myeloid leukemia. The New England Journal of Medicine, Vol. 363, No. 25, (December), pp. 2424-2433, ISNN 0028-4793

Ley, T.J.; Mardis, E.R.; Ding, L.; Fulton, B.; McLellan, M.D.; Chen, K.; Dooling, D.; DunfordShore, B.H.; McGrath, S.; Hickenbotham, M.; Cook, L.; Abbott, R.; Larson, D.E.; Koboldt, D.C.; Pohl, C.; Smith, S.; Hawkins, A.; Abbott, S.; Locke, D.; Hillier, L.W.; Miner, T.; Fulton, L.; Magrini, V.; Wylie, T.; Glasscock, J.; Conyers, J.; Sander, N.; Shi, X.; Osborne, J.R.; Minx, P.; Gordon, D.; Chinwalla, A.; Zhao, Y.; Ries, R.E.; Payton, J.E.; Westervelt, P.; Tomasson M.H.; Watson, M.; Baty, J.; Ivanovich, J.; Heath, S.; Shannon, W.D.; Nagarajan, R.; Walter, M.J.; Link, D.C.; Graubert, T.A.; DiPersio, J.F. \& Wilson, R.K. (2008) DNA sequencing of a cytogenetically normal acute myeloid leukaemia genome. Nature, Vol. 456, No. 7218, (November), pp. 6672, ISSN 0028-0836

Ley, T.J.; Minx, P.J.; Walter, M.J.; Ries, R.E.; Sun, H.; McLellan, M.; DiPersio, J.F.; Link, D.C.; Tomasson, M.H.; Graubert, T.A.; McLeod, H.; Khoury, H.; Watson, M.; Shannon, W.; Trinkaus, K.; Heath, S.; Vardiman, J.W.; Caligiuri, M.A.; Bloomfield, C.D.; Milbrandt, J.D.; Mardis, E.R. \& Wilson, R.K. (2003) A pilot study of highthroughput, sequence-based mutational profiling of primary human acute myeloid leukemia cell genomes. The Proceedings of the National Academy of Sciences of the USA, Vol. 100, No. 24, (November), pp. 14275-14280, ISSN 0027-8424

Li, Z.; Hann, S.R. (2009) The Myc-nucleophosmin-ARF network: a complex web unveiled. Cell Cycle, Vol. 8, No.17, (September), pp. 2703-2707, ISSN 1551-4005

Lin, L.I.; Chen, C.Y.; Lin, D.T.; Tsay, W.; Tang, J.L.; Yeh, Y.C.; Shen, H.L.; Su, F.H.; Yao, M.; Huang, S.Y. \& Tien, H.F. (2005). Characterization of CEBPA mutations in acute myeloid leukemia: most patients with CEBPA mutations have biallelic mutations and show a distinct immunophenotype of the leukemic cells. Clinical Cancer Research, Vol. 11, No. 4, (February), pp. 1372-1379, ISSN 1078-0432

Lin, T.C.; Hou, H.A.; Chou, W.C.; Ou, D.L.; Yu, S.L.; Tien, H.F. \& Lin, L.I. (2011) CEBPA methylation as a prognostic biomarker in patients with de novo acute myeloid leukemia. Leukemia, Vol. 25, No. 1, (January), pp. 32-40, ISSN 0887-6924

Liso, A.; Bogliolo, A.; Freschi, V.;, Martelli, M.P.;, Pileri, S.A.; Santodirocco, M.; Bolli, N.; Martelli, M.F. \& Falini, B. (2008) In human genome, generation of a nuclear export signal through duplication appears unique to nucleophosmin (NPM1) mutations and is restricted to AML. Leukemia, Vol. 22, No. 6, (June), pp. 1285-1289, ISSN 08876924

Loges, S.; Heil, G.; Bruweleit, M.; Schoder, V.; Butzal, M.; Fischer, U.; Gehling, U.M.; Schuch, G.; Hossfeld, D.K. \& Fiedler, W. (2005) Analysis of concerted expression of 
angiogenic growth factors in acute myeloid leukemia: expression of angiopoietin-2 represents an independent prognostic factor for overall survival. Journal of Clinical Oncology, Vol. 23, No. 6, (February), pp. 1109-1117, ISSN 0732-183X

Lugthart, S.; Figueroa, M.E.; Bindels, E.; Skrabanek, L.; Valk, P.J.; Li, Y.; Meyer, S.; ErpelinckVerschueren, C.; Greally, J.; Löwenberg, B.; Melnick, A. \& Delwel, R. (2011) Aberrant DNA hypermethylation signature in acute myeloid leukemia directed by EVI1. Blood, Vol. 117, No. 1, (January), pp. 234-241, ISSN 0006-4971

Luo, J.; Qi, C.; Xu, W.; Kamel-Reid, S.; Brandwein, J. \& Chang, H. (2010) Cytoplasmic expression of nucleophosmin accurately predicts mutation in the nucleophosmin gene in patients with acute myeloid leukemia and normal karyotype. American Journal of Clinical Pathology, Vol. 133, No. 1, (January), pp. 34-40, ISSN 0002-9173

Maggi Jr., L. B.; Kuchenruether, M.; Dadey, D.Y.; Schwope, R.M.; Grisendi, S.; Townsend, R.R.; Pandolfi, P.P. \& Weber, J.D. (2008) Nucleophosmin serves as a rate-limiting nuclear export chaperone for the mammalian ribosome Molecular and Cellular Biology, Vol. 28, No. 23, (December), pp. 7050-7065, ISSN 0270- 7306

Makishima, H.; Cazzolli, H.; Szpurka, H.; Dunbar, A.; Tiu, R.; Huh, J.; Muramatsu, H.; O'Keefe, C.; Hsi, E.; Paquette, R.L.; Kojima, S.; List, A.F.; Sekeres, M.A.; McDevitt, M.A. \& Maciejewski, J.P. (2009) Mutations of e3 ubiquitin ligase cbl family members constitute a novel common pathogenic lesion in myeloid malignancies. Journal of Clinical Oncology, Vol. 27, No. 36, (December), pp. 6109-6116, ISSN 0732$183 \mathrm{X}$

Marcucci, G.; Baldus, C.D.; Ruppert, A.S.; Radmacher, M.D.; Mrózek, K.; Whitman, S.P.; Kolitz, J.E.; Edwards, C.G.; Vardiman, J.W.; Powell, B.L.; Baer, M.R.; Moore, J.O.; Perrotti, D.; Caligiuri, M.A.; Carroll, A.J.; Larson, R.A.; de la Chapelle, A. \& Bloomfield, C.D. (2005) Overexpression of the ETS-related gene, ERG, predicts a worse outcome in acute myeloid leukemia with normal karyotype: a Cancer and Leukemia Group B study. Journal of Clinical Oncology, Vol. 23, No. 36, (December), pp. 9234-9242, ISSN 0732-183X

Marcucci, G.; Haferlach, T. \& Döhner, H. (2011a) Molecular genetics of adult acute myeloid leukemia: prognostic and therapeutic implications. Journal of Clinical Oncology, Vol. 29, No. 5, Feb 10; 29(5):475-486, ISSN 0732-183X

Marcucci, G.; Maharry, K.; Radmacher, M.D.; Mrózek, K.; Vukosavljevic, T.; Paschka, P.; Whitman, S.P.; Langer, C.; Baldus, C.D.; Liu, C.G.; Ruppert, A.S.; Powell, B.L.; Carroll, A.J.; Caligiuri, M.A.; Kolitz, J.E.; Larson, R.A. \& Bloomfield, C.D. (2008) Prognostic significance of, and gene and microRNA expression signatures associated with, CEBPA mutations in cytogenetically normal acute myeloid leukemia with high-risk molecular features: a Cancer and Leukemia Group B Study. Journal of Clinical Oncology, Vol. 26, No. 31, (November), pp. 5078-5087, ISSN 0732-183X

Marcucci, G.; Maharry, K.; Whitman, S.P.; Vukosavljevic, T.; Paschka, P.; Langer, C.; Mrózek, K.; Baldus, C.D.; Carroll, A.J.; Powell, B.L.; Kolitz, J.E.; Larson, R.A.; Bloomfield, C.D. \& Cancer and Leukemia Group B Study (2007) High expression levels of the ETS-related gene, ERG, predict adverse outcome and improve molecular risk-based classification of cytogenetically normal acute myeloid leukemia: a Cancer and Leukemia Group B Study. Journal of Clinical Oncology, Vol. 25, No. 22, (August), pp. 3337-3343, ISSN 0732-183X 
Marcucci, G.; Maharry, K.; Wu, Y.Z.; Radmacher, M.D.; Mrózek, K.; Margeson, D.; Holland, K.B.; Whitman, S.P.; Becker, H.; Schwind, S.; Metzeler, K.H.; Powell, B.L.; Carter, T.H.; Kolitz, J.E.; Wetzler, M.; Carroll, A.J.; Baer, M.R.; Caligiuri, M.A; Larson, R.A. \& Bloomfield, C.D. (2010) IDH1 and IDH2 gene mutations identify novel molecular subsets within de novo cytogenetically normal acute myeloid leukemia: a Cancer and Leukemia Group B study. Journal of Clinical Oncology, Vol. 28, No. 14 (May), pp. 2348-2355, ISSN 0732-183X

Marcucci, G.; Mrózek, K.; Radmacher, M.D.; Bloomfield, C.D. \& Croce, C.M. (2009) MicroRNA expression profiling in acute myeloid and chronic lymphocytic leukaemias. Best Practice \& Research Clinical Haematology, Vol. 22, No. 2, (June), pp. 239-248, ISSN 1521-6926

Marcucci, G.; Mrózek, K.; Radmacher, M.D.; Garzon, R. \& Bloomfield, C.D. (2011b) The prognostic and functional role of microRNAs in acute myeloid leukemia. Blood, Vol. 117, No. 4, (January), pp. 1121-1129, ISSN 0006-4971

Marcucci, G.; Strout, M.P.; Bloomfield, C.D. \& Caligiuri, M.A. (1998) Detection of unique ALL1 (MLL) fusion transcripts in normal human bone marrow and blood: distinct origin of normal versus leukemic ALL1 fusion transcripts. Cancer Research, Vol. 58, No. 4, (February), pp. 790-793, ISSN 0008-5472

Mardis, E.R. (2011) A decade's perspective on DNA sequencing technology. Nature, Vol. 470, No. 7333, (February), pp. 198-203, ISSN 0028-0836

Mardis, E.R.; Ding, L.; Dooling, D.J.; Larson, D.E.; McLellan M.D.; Chen, K.; Koboldt, D.C.; Fulton, R.S.; Delehaunty, K.D.; McGrath, S.D.; Fulton, L.A.; Locke, D.P.; Magrini, V.J.; Abbott, R.M.; Vickery, T.L.; Reed, J.S., Robinson, J.S.; Wylie, T.; Smith, S.M.; Carmichael, L.; Eldred, J.M.; Harris, C.C.; Walker, J.;, Peck, J.B.; Du, F.; Dukes, A.F.; Sanderson, G.E.; Brummett, A.M.; Clark, E.; McMichael, J.F.; Meyer, R.J.; Schindler, J.K.; Pohl, C.S.; Wallis, J.W.; Shi, X.; Lin, L.; Schmidt, H.; Tang, Y.; Haipek, C.; Wiechert, M.E.; Ivy, J.V.; Kalicki, J.; Elliott, G.; Ries, R.E.; Payton, J.E.; Westervelt, P.; Tomasson, M.H.; Watson, M.A.; Baty, J.; Heath, S.; Shannon, W.D.; Nagarajan, R.; Link, D.C.; Walter, M.J.; Graubert, T.A.; DiPersio, J.F.; Wilson, R.K. \& Ley, T.J. (2009) Recurring mutations found by sequencing an acute myeloid leukemia genome. The New England Journal of Medicine, Vol. 361, No. 11, (September), pp. 1058-1066, ISSN 0028-4793

Mariano, A.R.;, Colombo, E.; Luzi, L.; Martinelli, P.; Volorio, S.; Bernard, L.; Meani, N.; Bergomas, R.; Alcalay, M. \& Pelicci, P.G. (2006) Cytoplasmic localization of NPM in myeloid leukemias is dictated by gain-of-function mutations that create a functional nuclear export signal. Oncogene, Vol. 25, No. 31, (July), pp. 4376-4380, ISSN 0950-9232

Martelli, M.P.; Manes, N.; Liso, A.; Pettirossi, V.; Verducci Galletti, B.; Bigerna, B.; Pucciarini, A.; De Marco, M.F.; Pallotta, M.T.; Bolli, N.; Sborgia, M.; di Raimondo, F.; Fabbiano, F.; Meloni, G.; Specchia, G.; Martelli, M.F. \& Falini, B. (2008) A western blot assay for detecting mutant nucleophosmin (NPM1) proteins in acute myeloid leukaemia. Leukemia, Vol. 22, No.12, pp. 2285-2288, ISSN 0887-6924

Mead, A.J.; Gale, R.E.; Hills, R.K.; Gupta, M.; Young, B.D.; Burnett, A.K. \& Linch, D.C. (2008) Conflicting data on the prognostic significance of FLT3/TKD mutations in acute myeloid leukemia might be related to the incidence of biallelic disease. Blood, Vol. 112, No. 2, (July), pp. 444-445, ISSN 0006-4971 
Meani, N. \& Alcalay, M. (2009) Role of nucleophosmin in acute myeloid leukemia. Expert Review of Anticancer Therapy, Vol. 9, No. 9, (September), pp. 1283-1294, ISSN 14737140

Metzeler, K.H., Dufour, A.; Benthaus, T.; Hummel, M.; Sauerland, M.C.; Heinecke, A.; Berdel, W.E.; Büchner, T.; Wörmann, B.; Mansmann, U.; Braess, J.; Spiekermann, K.; Hiddemann, W.; Buske, C. \& Bohlander, S.K. (2009) ERG expression is an independent prognostic factor and allows refined risk stratification in cytogenetically normal acute myeloid leukemia: a comprehensive analysis of ERG, MN1, and BAALC transcript levels using oligonucleotide microarrays. Journal of Clinical Oncology, Vol. 27, No. 30, (October), pp. 5031-5038, ISSN 0732-183X

Metzeler, K.H.; Maharry, K.; Radmacher, M.D.; Mrózek, K.; Margeson, D.; Becker, H.; Curfman, J.; Holland, K.B.; Schwind, S.; Whitman, S.P.; Wu, Y.Z.; Blum, W.; Powell, B.L.; Carter, T.H.; Wetzler, M.; Moore, J.O.; Kolitz, J.E.; Baer, M.R.; Carroll, A.J.; Larson, R.A.; Caligiuri, M.A.; Marcucci, G. \& Bloomfield, C.D. (2011) TET2 Mutations Improve the New European LeukemiaNet Risk Classification of Acute Myeloid Leukemia: A Cancer and Leukemia Group B Study. Journal of Clinical Oncology, Feb 22, [Epub ahead of print], ISSN 0732-183X

Miwa, H.; Beran, M. \& Saunders, G.F. (1992) Expression of the Wilms' tumor gene (WT1) in human leukemias. Leukemia, Vol. 6, No. 5, (May), pp. 405-409, ISSN 0887-6924

Miyawaki, S.; Hatsumi, N.; Tamaki, T.; Naoe, T.; Ozawa, K.; Kitamura, K.; Karasuno, T.; Mitani, K.; Kodera, Y.; Yamagami, T. \& Koga, D. (2010) Prognostic potential of detection of WT1 mRNA level in peripheral blood in adult acute myeloid leukemia. Leukemia \& Lymphoma, Vol. 51, No. 10, (October), pp. 1855-1861, ISSN 1042-8194

Mohr, F.; Döhner, K.; Buske, C. \& Rawat, V.P. (2011) TET Genes: new players in DNA demethylation and important determinants for stemness. Experimental Hematology,Vol. 39, No. 3, (March), pp. 272-281, ISSN 0301-472X

Motyckova, G. \& Stone R.M. (2010) The role of molecular tests in acute myeloid leukemia treatment decisions. Current Hematology Malignancies Report, Vol. 5, pp. 109-117, ISSN 1558-822X

Mourah, S.; Porcher, R.; Lescaille, G.; Rousselot, P.; Podgorniak, M.P.; Labarchede, G.; Naimi, B.;Medioni, J.; Dombret, H. \& Calvo, F. (2009) Quantification of VEGF isoforms and VEGFR transcripts by qRT-PCR and their significance in acute myeloid leukemia. The International Journal of Biological Markers, Vol. 24, No. 1, (January-March), pp. 22-31, ISSN 1724-6008

Mrózek, K.; Döhner, H. \& Bloomfield, C.D. (2007) Influence of new molecular prognostic markers in patients with karyotypically normal acute myeloid leukemia: recent advances. Current Opinion in Hematology, Vol. 14, No. 2, (March), pp. 106-114, ISSN 1065-6251

Nakao, M.; Yokota, S.; Iwai, T.; Kaneko, H.; Horiike, S.; Kashima, K.; Sonoda, Y.; Fujimoto, T. \& Misawa, S. (1996) Internal tandem duplication of the flt3 gene found in acute myeloid leukemia. Leukemia, Vol. 10, No. 12, (December), pp. 1911-1918, ISSN 08876924

Nana-Sinkam, P. \& Croce, C.M. (2010) MicroRNAs in diagnosis and prognosis in cancer: what does the future hold? Pharmacogenomics, Vol. 11, No. 5, (May), pp. 667-669, ISSN 1462-2416 
Naoe, T. \& Kiyoi, H. (2010) Normal and oncogenic FLT3. Cellular and Molecular Life Sciences, Vol. 61, No. 23, (December), pp. 2932-2938, ISSN 1420-682X

Narahara K, Kimura S, Kikkawa K, Takahashi Y, Wakita Y, Kasai R, Nagai S, Nishibayashi Y, Kimoto H. (1985) Probable assignment of soluble isocitrate dehydrogenase (IDH1) to 2q33.3. Human Genetics, Vol. 71, No.1, pp. 37-40, ISSN 0340-6717

Newton, C.R.; Graham, A.; Heptinstall, L.E.; Powell, S.J.; Summers, C.; Kalsheker, N.; Smith, J.C. \& Markham, A.F. (1989) Analysis of any point mutation in DNA. The amplification refractory mutation system (ARMS). Nucleic Acids Research, Vol. 17, No. 7, (April), pp. 2503-2516, ISSN 0305-1048

Nibourel, O.; Kosmider, O.; Cheok, M.; Boissel, N.; Renneville, A.; Philippe, N.; Dombret, H.; Dreyfus, F.; Quesnel, B.; Geffroy, S.; Quentin, S.; Roche-Lestienne, C.; Cayuela, J.M.; Roumier, C.; Fenaux, P.; Vainchenker, W.; Bernard, O.A.; Soulier, J.; Fontenay, M. \& Preudhomme, C. (2010) Incidence and prognostic value of TET2 alterations in de novo acute myeloid leukemia achieving complete remission. Blood, Vol. 116, No. 7, (August), pp. 1132-1135, ISSN 0006-4971

Nilson, I.; Löchner, K.; Siegler, G.; Greil, J.; Beck, J.D.; Fey, G.H. \& Marschalek, R. (1996) Exon/intron structure of the human ALL-1 (MLL) gene involved in translocations to chromosomal region 11q23 and acute leukaemias. British Journal of Haematology, Vol. 93, No. 4, (June), pp. 966-972, ISSN 0007-1048

Noordermeer, S.M.; Tönnissen, E.; Vissers, I.; van der Heijden, A.; van de Locht, L.T.; DeutzTerlouw, P.P.; Marijt, E.W.; Jansen, J.H. \& van der Reijden, B.A. (2011) Rapid identification of IDH1 and IDH2 mutations in acute myeloid leukaemia using high resolution melting curve analysis. British Journal of Haematology, Vol. 152, No. 4, (February), pp. 493-496, ISSN 0007-1048

Oelschlaegel, U.; Koch, S.; Mohr, B.; Schaich, M.; Falini, B.; Ehninger, G. \& Thiede, C. (2010) Rapid flow cytometric detection of aberrant cytoplasmic localization of nucleophosmin (NPMc) indicating mutant NPM1 gene in acute myeloid leukemia. Leukemia, Vol. 24, No.10, (October), pp. 1813-1816, ISSN 0887-6924

Oh, I.U.; Inazawa, J.; Kim, Y.O.; Song, B.J. \& Huh, T.L. (1996) Assignment of the human mitochondrial NADP(+)-specific isocitrate dehydrogenase (IDH2) gene to 15q26.1 by in situ hybridization. Genomics, Vol. 38, No. 1, (November), pp.104-106, ISSN 0888-7543

Orita, M.; Iwahana, H.; Kanazawa, H.; Hayashi, K. \& Sekiya, T. (1989) Detection of polymorphisms of human DNA by gel electrophoresis as single-strand conformation polymorphisms. The Proceedings of the National Academy of Sciences of the USA, Vol. 86, No. 8, (April), pp. 2766-2770, ISSN 0027-8424

Orou, A.; Fechner, B.; Utermann, G. \& Menzel, H.J. (1995) Allele-specific competitive blocker PCR: a one-step method with applicability to pool screening. Human Mutation, Vol. 6, No. 2, (February), pp. 163-169, ISSN1059-7794

Otten, J.; Schmitz, L.; Vettorazzi, E.; Schultze, A.; Marx, A.H.; Simon, R.; Krauter, J.; Loges, S.; Sauter, G.; Bokemeyer, C. \& Fiedler, W. (2011) Expression of TGF- $\beta$ receptor ALK-5 has a negative impact on outcome of patients with acute myeloid leukemia. Leukemia, Vol. 25, No. 2, (February), pp. 375-379, ISSN 0887-6924

Owen, C.; Fitzgibbon, J. \& Paschka, P. (2010) The clinical relevance of Wilms Tumor I (WT1) gene mutations in acute leukaemia. Hematological Oncology, Vol. 28, (December), pp. 13-19, ISSN 1099-1069 
Pabst, T.; Eyholzer, M.; Fos, J. \& Mueller, B.U. (2009) Heterogeneity within AML with CEBPA mutations; only CEBPA double mutations, but not single CEBPA mutations are associated with favourable prognosis. British Journal of Cancer, Vol. 100, No. 8, (April), pp. 1343-1346, ISSN 0007-0920

Pabst, T. \& Mueller, B.U. (2007) Transcriptional dysregulation during myeloid transformation in AML. Oncogene, Vol. 26, No. 47, (October), pp. 6829-6837, ISSN 0950-9232

Pabst, T.; Mueller, B.U.; Zhang, P.; Radomska, H.S.; Narravula, S.; Schnittger, S.; Behre, G.; Hiddemann, W. \& Tenen, D.G. (2001) Dominant-negative mutations of CEBPA, encoding CCAAT/enhancer binding protein-alpha (C/EBPalpha), in acute myeloid leukemia. Nature Genetics, Vol. 27, No. 3, (March), pp. 263-270, ISSN 1061-4036

Paschka, P.; Marcucci, G.; Ruppert, A.S.; Whitman, S.P.; Mrózek, K.; Maharry, K.; Langer, C.; Baldus, C.D.; Zhao, W.; Powell, B.L.; Baer, M.R.; Carroll, A.J.; Caligiuri, M.A.; Kolitz, J.E.; Larson, R.A. \& Bloomfield, C.D. (2008) Wilms' tumor 1 gene mutations independently predict poor outcome in adults with cytogenetically normal acute myeloid leukemia: a cancer and leukemia group B study. Journal of Clinical Oncology, Vol. 26, No. 28 (October), pp. 4595-4602, ISSN 0732-183X

Paschka, P.; Schlenk, R.F.; Gaidzik, V.I.; Habdank, M.; Krönke, J.; Bullinger, L.; Späth, D.; Kayser, S.; Zucknick, M.; Götze, K.; Horst, H.A.; Germing, U.; Döhner, H. \& Döhner, K. (2010) IDH1 and IDH2 mutations are frequent genetic alterations in acute myeloid leukemia and confer adverse prognosis in cytogenetically normal acute myeloid leukemia with NPM1 mutation without FLT3 internal tandem duplication. Journal of Clinical Oncology, Vol. 28, No. 22 (August), pp. 3636-3643, ISSN 0732-183X

Patel, K.P.; Ravandi, F.; Ma, D.; Paladugu, A.; Barkoh, B.A.; Medeiros, L.J. \& Luthra, R. (2011) Acute myeloid leukemia with IDH1 or IDH2 mutation: frequency and clinicopathologic features. American Journal of Clinical Pathology, Vol. 135, No. 1, (January), pp. 35-45, ISSN 0002-9173

Paydas, S.; Tanriverdi, K.; Yavuz, S.; Disel, U.; Baslamisli, F. \& Burgut, R. (2005) PRAME mRNA levels in cases with acute leukemia: clinical importance and future prospects. American Journal of Hematology, Vol. 79, No. 4, (August), pp. 257-261, ISSN 0361-8609

Perry, D.J. (1999) Screening for Mutations in DNA by Single-Stranded Conformation Polymorphism (SSCP) Analysis. Methods in Molecular Medicine, Vo1. 31, pp. 105-10, ISSN 1543-1894

Pfaffl, M.W. (2001) A new mathematical model for relative quantification in real-time RTPCR. Nucleic Acids Research, Vol. 29, No. 9, (May), e45, ISSN 0305-1048

Pfaffl, M.W., Horgan, G.W. \& Dempfle, L. (2002) Relative expression software tool (REST) for group-wise comparison and statistical analysis of relative expression results in real-time PCR. Nucleic Acids Research May 1; 30(9):e36. ISSN 0305-1048

Preudhomme, C.; Sagot, C.; Boissel, N.; Cayuela, J.M.; Tigaud, I.; de Botton, S.; Thomas, X.; Raffoux, E.; Lamandin, C.; Castaigne, S.; Fenaux, P.; Dombret, H. \& ALFA Group. (2002) Favorable prognostic significance of CEBPA mutations in patients with de novo acute myeloid leukemia: a study from the Acute Leukemia French Association (ALFA). Blood, Vol. 100, No. 8, (October), pp. 2717-2723, ISSN 0006-4971 
Qin, Y.; Zhu, H.; Jiang, B.; Li, J.; Lu, X.; Li, L.; Ruan, G.; Liu, Y.; Chen, S. \& Huang, X. (2009) Expression patterns of WT1 and PRAME in acute myeloid leukemia patients and their usefulness for monitoring minimal residual disease. Leukemia Research, Vol. 33, No. 3, (March), pp. 384-390, ISSN 0145-2126

Radmacher, M.D.; Marcucci, G.; Ruppert, A.S.; Mrózek, K.; Whitman, S.P.; Vardiman, J.W.; Paschka, P.; Vukosavljevic, T.; Baldus, C.D.; Kolitz, J.E.; Caligiuri, M.A.; Larson, R.A.; Bloomfield, C.D. \& Cancer and Leukemia Group B. (2006) Independent confirmation of a prognostic gene-expression signature in adult acute myeloid leukemia with a normal karyotype: a Cancer and Leukemia Group B study. Blood, Vol. 108, No. 5, (September), pp. 1677-1683, ISSN 0006-4971

Radomska, H.S.; Bassères DS, Zheng R, Zhang P, Dayaram T, Yamamoto Y, Sternberg DW, Lokker N, Giese NA, Bohlander SK, Schnittger S, Delmotte MH, Davis RJ, Small D, Hiddemann W, Gilliland DG, Tenen DG. (2006) Block of C/EBP alpha function by phosphorylation in acute myeloid leukemia with FLT3 activating mutations. The Journal of Experimental Medicine, Vol. 203, No. 2, (February), pp. 371-381, ISSN 00221007

Ramsingh, G.; Koboldt, D.C.; Trissal, M.; Chiappinelli, K.B.; Wylie, T.; Koul, S.; Chang, L.W.; Nagarajan, R.; Fehniger, T.A.; Goodfellow, P.; Magrini, V.; Wilson, R.K.; Ding, L.; Ley, T.J.; Mardis, E.R. \& Link, D.C. (2010) Complete characterization of the microRNAome in a patient with acute myeloid leukemia. Blood, Vol. 116, No. 24, (December), pp. 5316-5326, ISSN 0006-4971

Rau, R. \& Brown, P. (2009) Nucleophosmin (NPM1) mutations in adult and childhood acute myeloid leukaemia: towards definition of a new leukaemia entity. Hematological Oncology, Vol. 27, No. 4, (December), pp. 171-181, ISSN 1099-1069

Ravandi, F.; Kantarjian, H.; Faderl, S.; Garcia-Manero, G.; O'Brien, S.; Koller, C.; Pierce, S.; Brandt, M.; Kennedy, D.; Cortes, J. \& Beran, M. (2010) Outcome of patients with FLT3-mutated acute myeloid leukemia in first relapse. Leukemia Research, Vol. 34, No. 6, (June), pp. 752-756, ISSN 0145-2126

Rázga, F.; Dvořáková, D., Jurček, T., Ježǐšková, I., Křístková, Z. \& Mayer, J. (2009) CEBPA gene mutational status: a complete screening using high-resolution melt curve analysis. Molecular Diagnosis \& Therapy, Vol. 13, No. 3, pp. 195-200, ISSN 1177-1062

Reindl, C.; Quentmeier, H.; Petropoulos, K.; Greif, P.A.; Benthaus, T.; Argiropoulos, B.; Mellert, G.; Vempati, S.; Duyster, J.; Buske, C.; Bohlander, S.K.; Humphries, K.R.; Hiddemann, W. \& Spiekermann, K. (2009) CBL exon 8/9 mutants activate the FLT3 pathway and cluster in core binding factor $/ 11 \mathrm{q}$ deletion acute myeloid leukemia/myelodysplastic syndrome subtypes. Clinical Cancer Research, Vol. 15, No. 7, (April), pp. 2238-2247, ISSN 1078-0432

Renneville, A.; Boissel, N.; Zurawski, V.; Llopis, L.; Biggio, V.; Nibourel, O.; Philippe, N.; Thomas, X.; Dombret, H. \& Preudhomme, C. (2009) Wilms tumor 1 gene mutations are associated with a higher risk of recurrence in young adults with acute myeloid leukemia: a study from the Acute Leukemia French Association. Cancer, Vol. 115, No. 16, (August), pp. 3719-3727, ISSN 1097-0142

Ritter, M.; Kim, T.D.; Lisske, P.; Thiede, C.; Schaich, M. \& Neubauer, A. (2004) Prognostic significance of N-RAS and K-RAS mutations in 232 patients with acute myeloid leukemia. Haematologica, Vol. 89, No. 11, pp. 1397-1399, ISSN 0390-6078 
Rocquain, J.; Carbuccia, N.; Trouplin, V.; Raynaud, S.; Murati, A.;, Nezri, M.; Tadrist, Z.; Olschwang, S.; Vey, N.; Birnbaum, D.; Gelsi-Boyer, V. \& Mozziconacci, M.J. (2010) Combined mutations of ASXL1, CBL, FLT3, IDH1, IDH2, JAK2, KRAS, NPM1, NRAS, RUNX1, TET2 and WT1 genes in myelodysplastic syndromes and acute myeloid leukemias. BMC Cancer, Vol. 10, (August), p. 401, ISSN 1471-2407

Rodríguez-Paredes, M. \& Esteller,M. (2011) Cancer epigenetics reaches mainstream oncology. Nature Medicine, Vol. 17, No. 3, (March), pp. 330-339, ISSN 1546-170X

Roti, G.; Rosati, R.; Bonasso, R.; Gorello, P.; Diverio, D.; Martelli, M.F.; Falini, B.; Mecucci, C. \& Gruppo Italiano Malattie Ematologiche dell' Adulto Working Party. (2006) Denaturing high-performance liquid chromatography: a valid approach for identifying NPM1 mutations in acute myeloid leukemia. Journal of Molecular Diagnostics, Vol. 8, No. 2, (May), pp. 254-259, ISSN 1525-1578

Santamaría, C.; Chillón, M.C.; García-Sanz, R.; Pérez, C.; Caballero, M.D.; Mateos, M.V.; Ramos, F.; de Coca, A.G.; Alonso, J.M.; Giraldo, P.; Bernal, T.; Queizán, J.A.; Rodríguez, J.N.; Puig, N.; Balanzategui, A.; Sarasquete, M.E.; Alcoceba, M.; DíazMediavilla, J.; San Miguel, J. \& González, M. (2010) BAALC is an important predictor of refractoriness to chemotherapy and poor survival in intermediate-risk acute myeloid leukemia (AML). Annals of Hematology, Vol. 89, No. 5, (May), pp. 453458, ISSN 0939-5555

Santamaría, C.M.; Chillón, M.C.; García-Sanz, R.; Pérez, C.; Caballero, M.D.; Ramos, F.; de Coca, A.G.; Alonso, J.M.; Giraldo, P.; Bernal, T.; Queizán, J.A.; Rodriguez, J.N.; Fernández-Abellán, P.; Bárez, A.; Peñarrubia, M.J.; Balanzategui, A.; Vidriales, M.B.; Sarasquete, M.E.; Alcoceba, M.; Díaz-Mediavilla, J.; San Miguel, J.F. \& Gonzalez, M. (2009) Molecular stratification model for prognosis in cytogenetically normal acute myeloid leukemia. Blood, Vol. 114, No. 1, (July), pp. 148-152, ISSN 0006-4971

Sárová, I.; Brezinová, J.; Zemanová, Z.; Lizcová, L.; Berková, A.; Izáková, S.; Malinová, E.; Fuchs, O.; Kostecka, A.; Provazníková, D.; Filkuková, J.; Maaloufová, J.; Starý, J. \& Michalová, K. (2009) A partial nontandem duplication of the MLL gene in four patients with acute myeloid leukemia. Cancer Genetics and Cytogenetics, Vol. 195, No. 2, (December), pp. 150-156, ISSN 0165-4608

Savkur, R. S. \& Olson, M. O. (1998) Preferential cleavage in pre-ribosomal RNA by protein B23 endoribonuclease. Nucleic Acids Research, Vol. 26, No. 19, (October), pp. 45084515, ISSN 0305-1048

Schlenk, R.F. \& Döhner, K. (2009) Impact of new prognostic markers in treatment decisions in acute myeloid leukemia. Current Opinion in Hematology, Vol. 16, pp. 98-104, ISSN 1065-6251

Schlenk, R.F.; Döhner, K.; Krauter, J.; Fröhling, S.; Corbacioglu, A.; Bullinger, L.; Habdank, M.; Späth, D.; Morgan, M.; Benner, A.; Schlegelberger, B.; Heil, G.; Ganser, A.; Döhner, H. \& German-Austrian Acute Myeloid Leukemia Study Group. (2008) Mutations and treatment outcome in cytogenetically normal acute myeloid leukemia. The New England Journal of Medicine, Vol. 358, No. 18, (May), pp. 19091918, ISSN 0028-4793

Schnittger, S.; Haferlach, C.; Ulke, M.; Alpermann, T.; Kern, W. \& Haferlach, T. (2010) IDH1 mutations are detected in 6.6\% of 1414 AML patients and are associated with intermediate risk karyotype and unfavorable prognosis in adults younger than 60 
years and unmutated NPM1 status. Blood, Vol. 116, No. 25, (December), pp. 54865496, ISSN 0006-4971

Schnittger, S.; Kern, W.; Tschulik, C.; Weiss, T.; Dicker, F.; Falini, B.; Haferlach, C. \& Haferlach, T. (2009) Minimal residual disease levels assessed by NPM1 mutationspecific RQ-PCR provide important prognostic information in AML. Blood, Vol.114, No. 11, (September),pp. 2220-2231, ISSN 0006-4971

Schnittger, S.; Kinkelin, U.; Schoch, C.; Heinecke, A.; Haase, D.; Haferlach, T.; Büchner, T.; Wörmann, B.; Hiddemann, W. \& Griesinger, F. (2000) Screening for MLL tandem duplication in 387 unselected patients with AML identify a prognostically unfavorable subset of AML. Leukemia, Vol. 14, No. 5, (May), pp. 796-804, ISSN 08876924

Schnittger, S.; Wörmann, B.; Hiddemann, W. \& Griesinger, F. (1998) Partial tandem duplications of the MLL gene are detectable in peripheral blood and bone marrow of nearly all healthy donors. Blood, Vol. 92. No. 5, (September), pp. 1728-1734, ISSN 0006-4971

Scholl, S.; Theuer, C.; Scheble, V.; Kunert, C.; Heller, A.; Múgge, L.O.; Fricke, H.J.; Höfken, K. \& Wedding, U. (2008) Clinical impact of nucleophosmin mutations and Flt3 internal tandem duplications in patients older than $60 \mathrm{yr}$ with acute myeloid leukaemia. European Journal of Haematology, Vol. 80, No. 3, (March), pp. 208-215, ISSN 0902-4441

Schwind, S.; Marcucci, G.; Maharry, K.; Radmacher, M.D.; Mrózek, K.; Holland, K.B.; Margeson, D.; Becker, H.; Whitman, S.P.; Wu, Y.Z.; Metzeler, K.H.; Powell, B.L.; Kolitz, J.E.; Carter, T.H.; Moore, J.O.; Baer, M.R.; Carroll, A.J.; Caligiuri, M.A.; Larson, R.A. \& Bloomfield, C.D. (2010) BAALC and ERG expression levels are associated with outcome and distinct gene and microRNA expression profiles in older patients with de novo cytogenetically normal acute myeloid leukemia: a Cancer and Leukemia Group B study. Blood, Vol. 116. No. 25, (December), pp. 56605669, ISSN 0006-4971

Seyama, T.; Ito, T.; Hayashi, T.; Mizuno, T.; Nakamura, N. \& Akiyama, M. (1992) A novel blocker-PCR method for detection of rare mutant alleles in the presence of an excess amount of normal DNA. Nucleic Acids Research, Vol. 20, No. 10, (May), pp. 2493-2496, ISSN 0305-1048

Shook, D.; Coustan-Smith, E.; Ribeiro, R.C.; Rubnitz, J.E. \& Campana, D. (2009) Minimal residual disease quantitation in acute myeloid leukemia. Clinical Lymphoma \& Myeloma, Vol. 9, Suppl. 3, pp. S281-S285, ISSN 1557-9190

Small, D. (2008) Targeting FLT3 for the treatment of leukemia. Seminars in Hematology, Vol. 45, No. 3, Suppl. 2 (July), pp. S17-S21, ISSN 0037-1963

Smith, M.L.; Hills, R.K. \& Grimwade, D. (2011) Independent prognostic variables in acute myeloid leukaemia. Blood Reviews, Vol. 25, No. 1, (January), pp. 39-51, ISSN 0268960X

Spoo, A.C.; Lübbert, M.; Wierda, W.G. \& Burger, J.A. (2007) CXCR4 is a prognostic marker in acute myelogenous leukemia. Blood, Vol. 109, No. 2, (January), pp. 786-791, ISSN 0006-4971

Steinbach, D. \& Legrand, O. (2007) ABC transporters and drug resistance in leukemia: was P-gp nothing but the first head of the Hydra? Leukemia, Vol. 21, No. 6, (June), pp. 1172-1176, ISSN 0887-6924 
Steinbach, D.; Pfaffendorf, N.; Wittig, S.\& Gruhn, B. (2007) PRAME expression is not associated with down-regulation of retinoic acid signaling in primary acute myeloid leukemia. Cancer Genetics and Cytogenetics, Vol. 177, No. 1, (August), pp. 51-54, ISSN 0165-4608

Steudel, C.; Wermke, M.; Schaich, M.; Schäkel, U.; Illmer, T.; Ehninger, G. \& Thiede, C. (2003) Comparative analysis of MLL partial tandem duplication and FLT3 internal tandem duplication mutations in 956 adult patients with acute myeloid leukemia. Genes Chromosomes Cancer, Vol. 37, No. 3, (July), pp. 237-251, ISSN 1045-2257

Strout, M.P.; Marcucci, G.; Bloomfield, C.D. \& Caligiuri, M.A. (1998) The partial tandem duplication of ALL1 (MLL) is consistently generated by Alu-mediated homologous recombination in acute myeloid leukemia. The Proceedings of the National Academy of Sciences of the USA, Vol. 95, No. 5, pp. 2390-2395, ISSN 0027-8424

Suh, H.C.; Gooya, J.; Renn, K.; Friedman, A.D.; Johnson, P.F. \& Keller, J.R. (2006) $\mathrm{C} /$ EBPalpha determines hematopoietic cell fate in multipotential progenitor cells by inhibiting erythroid differentiation and inducing myeloid differentiation. Blood, Vol. 107, No. 11, (June), pp. 4308-4316, ISSN 0006-4971

Szankasi, P.; Ho, A.K.; Bahler, D.W.; Efimova, O. \& Kelley, T.W. (2011) Combined testing for CCAAT/enhancer-binding protein alpha (CEBPA) mutations and promoter methylation in acute myeloid leukemia demonstrates shared phenotypic features. Leukemia Research, Vol. 35, No. 2, (February), pp. 200-207, ISSN 0145-2126

Szotkowski, T.; Muzik, J.; Voglova, J.; Koza, V.; Maaloufova, J.; Kozak, T.; Jarosova, M.; Michalova, K.; Zak, P.; Steinerova, K.; Vydra, J.; Lanska, M.; Katrincsakova, B.; Sicova, K.; Pavlik, T.; Dusek, L. \& Indrak, K. (2010) Prognostic factors and treatment outcome in 1,516 adult patients with de novo and secondary acute myeloid leukemia in 1999-2009 in 5 hematology intensive care centers in the Czech Republic. Neoplasma, Vol. 57, No. 6, pp. 578-589, ISSN 0028-2685

Tan, A.Y.; Westerman, D.A.; Carney, D.A.; Seymour, J.F.; Juneja, S. \& Dobrovic, A. (2008) Detection of NPM1 exon 12 mutations and FLT3 - internal tandem duplications by high resolution melting analysis in normal karyotype acute myeloid leukemia. Journal of Hematology \& Oncology, Vol. 1 , (July), pp. 10, ISSN 1756-8722

Taberlay, P.C. \& Jones, P.A. (2011) DNA methylation and cancer. Prog Drug Res. 2011;67:123

Tang, J.L.; Hou, H.A.; Chen, C.Y.; Liu, C.Y.; Chou, W.C.; Tseng, M.H.; Huang, C.F.; Lee, F.Y.; Liu, M.C.; Yao, M.; Huang, S.Y.; Ko, B.S.; Hsu, S.C.; Wu, S.J.; Tsay, W.; Chen, Y.C.; Lin, L.I. \&, Tien, H.F. (2009) AML1/RUNX1 mutations in 470 adult patients with de novo acute myeloid leukemia: prognostic implication and interaction with other gene alterations. Blood, Vol. 114, No. 26, (December), pp. 5352-5361, ISSN 0006-4971

Taskesen, E.; Bullinger, L.; Corbacioglu, A.; Sanders, M.A.; Erpelinck, C.A.; Wouters, B.J., van der Poel-van de Luytgaarde, S.C.; Damm, F.; Krauter, J.; Ganser, A.; Schlenk, R.F.; Löwenberg, B.; Delwel, R.; Döhner, H.; Valk, P.J. \& Döhner, K. (2011) Prognostic impact, concurrent genetic mutations, and gene expression features of AML with CEBPA mutations in a cohort of 1182 cytogenetically normal AML patients: further evidence for CEBPA double mutant AML as a distinctive disease entity. Blood, Vol. 117, No. 8, (February), pp. 2469-2475, ISSN 0006-4971 
Tavernier-Tardy, E.; Cornillon, J.; Campos, L.; Flandrin, P.; Duval, A.; Nadal, N. \& Guyotat, D. (2009) Prognostic value of CXCR4 and FAK expression in acute myelogenous leukemia. Leukemia Research, Vol. 33, No. 6, (June), pp. 764-768, ISSN 0145-2126

Tenen, D.G.; Hromas, R.; Licht, J.D. \& Zhang, D.E. (1997) Transcription factors, normal myeloid development, and leukaemia, Blood, Vol. 90, No. 2, (July), pp. 489-519, ISSN 0006-4971

Thol, F.; Damm, F.; Wagner, K.; Göhring, G.; Schlegelberger, B.; Hoelzer, D.; Lübbert, M.; Heit, W.; Kanz, L.; Schlimok, G.; Raghavachar, A.; Fiedler, W.; Kirchner, H.; Heil, G.; Heuser, M.; Krauter, J. \& Ganser,A. (2010) Prognostic impact of IDH2 mutations in cytogenetically normal acute myeloid leukemia. Blood, Vol. 116, No. 4, (July), pp. 614-616, ISSN 0006-4971

Trnková, Z.; Bedrlíková, R.; Marková, J.; Michalová, K.; Stöckbauer, P. \& Schwarz, J. (2007) Semiquantitative RT-PCR evaluation of the MDR1 gene expression in patients with acute myeloid leukemia. Neoplasma, Vol. 54, No. 5, pp. 387-390, ISSN 0028-2685

Ugozzoli, L.A.; Latorra, D.; Puckett, R.; Arar, K. \& Hamby, K. (2004) Real-time genotyping with oligonucleotide probes containing locked nucleic acids. Analytical Biochemistry, Vol. 324, No. 1, (January), pp. 143-152, ISSN 0003-2697

Ugrinova, I.; K. Monier, K.; Ivaldi, C.; Thiry, M.; Storck, S.; Mongelard, F. \& Bouvet, P. (2007) Inactivation of nucleolin leads to nucleolar disruption, cell cycle arrest and defects in centrosome duplication. BMC Molecular Biology, Vol. 8, (August) article 66, ISSN 1471-2199

Vardiman, J.W.; Thiele, J.; Arber, D.A.; Brunning, R.D.; Borowitz, M.J.; Porwit, A.; Harris, N.L.; Le Beau, M.M.; Hellström-Lindberg, E.; Tefferi, A. \& Bloomfield, C.D. (2009) The 2008 revision of the World Health Organization (WHO) classification of myeloid neoplasms and acute leukemia: rationale and important changes. Blood, Vol. 114, No. 5, (July), pp. 937-951, ISSN 0006-4971

Vaughn, C.P. \& Elenitoba-Johnson, K.S. (2004) High-resolution melting analysis for detection of internal tandem duplications. Journal of Molecular Diagnostics, Vol. 6, No. 3, (August), pp. 211-216, ISSN 1525-1578

Verhaak, R.G.; Goudswaard, C.S.; van Putten, W.; Bijl, M.A.; Sanders, M.A.; Hugens, W.; Uitterlinden, A.G.; Erpelinck, C.A.; Delwel, R.; Löwenberg, B. \& Valk, P.J. (2005) Mutations in nucleophosmin (NPM1) in acute myeloid leukemia (AML): association with other gene abnormalities and previously established gene expression signatures and their favorable prognostic significance. Blood, Vol. 106, No. 12, (December), pp. 3747-3754, ISSN 0006-4971

Verhaak, R.G.; Wouters, B.J.; Erpelinck, C.A.; Abbas, S.; Beverloo, H.B.; Lugthart, S.; Löwenberg, B.; Delwel, R. \& Valk, P.J. (2009) Prediction of molecular subtypes in acute myeloid leukemia based on gene expression profiling. Haematologica, Vol. 94, No. 1, (January), pp. 131-134, ISSN 0390-6078

Virappane, P.; Gale, R.; Hills, R.; Kakkas, I.; Summers, K.; Stevens, J.; Allen, C.; Green.; C, Quentmeier, H.; Drexler, H.; Burnett, A.; Linch, D.; Bonnet, D.; Lister, T.A. \& Fitzgibbon J. (2008) Mutation of the Wilms' tumor 1 gene is a poor prognostic factor associated with chemotherapy resistance in normal karyotype acute myeloid leukemia: the United Kingdom Medical Research Council Adult Leukaemia Working Party. Mutation of the Wilms' tumor 1 gene is a poor prognostic factor associated with chemotherapy resistance in normal karyotype acute myeloid 
leukemia: the United Kingdom Medical Research Council Adult Leukaemia Working Party. Journal of Clinical Oncology, Vol. 26, No. 33, (November), pp. 54295435, ISSN 0732-183X

Wagner, K.; Damm, F.; Göhring, G.; Görlich, K.; Heuser, M.; Schäfer, I.; Ottmann, O.; Lübbert, M.; Heit, W.; Kanz, L.; Schlimok, G.; Raghavachar, A.A.; Fiedler, W.; Kirchner, H.H.; Brugger, W.; Zucknick, M.; Schlegelberger, B.; Heil, G.; Ganser, A. \& Krauter, J. (2010) Impact of IDH1 R132 mutations and an IDH1 single nucleotide polymorphism in cytogenetically normal acute myeloid leukemia: SNP rs11554137 is an adverse prognostic factor. Journal of Clinical Oncology, Vol. 28, No. 14, (May), pp. 5078-5087, ISSN 0732-183X

Wang, N.D.; Finegold, M.J.; Bradley, A.; Ou, C.N.; Abdelsayed, S.V.; Wilde, M.D.; Taylor, L.R.; Wilson, D.R. \& Darlington, G. (1995) Impaired energy homeostasis in C/EBP alpha knockout mice. Science, Vol. 269, No. 5227, (August) pp. 1108-1112, ISSN 0036-8075

Ward, P.S,; Patel, J.; Wise, D.R.; Abdel-Wahab, O.; Bennett, B.D.; Coller, H.A.; Cross, J.R.; Fantin, V.R.; Hedvat, C.V.; Perl, A.E.; Rabinowitz, J.D.; Carroll, M.; Su, S.M.; Sharp, K.A.; Levine, R.L. \& Thompson, C.B. (2010) The common feature of leukemiaassociated IDH1 and IDH2 mutations is a neomorphic enzyme activity converting alpha-ketoglutarate to 2-hydroxyglutarate. Cancer Cell, Vol. 17, No. 3, (March), pp. 225-234, ISSN 1535-6108

Watanabe, Y. \& Maekawa, M. (2010) Methylation of DNA in cancer. Advances in Clinical Chemistry, Vol. 52, pp. 145-167. ISSN 0065-2423

Weisberg, E.; Barrett, R.; Liu, Q.; Stone, R.; Gray, N. \& Griffin, J.D. (2009) FLT3 inhibition and mechanisms of drug resistance in mutant FLT3-positive AML. Drug Resistance Updates, Vol. 12, No. 3, (June), pp. 81-89, ISSN 1368-7646

Whitman, S.P.; Hackanson, B.; Liyanarachchi, S.; Liu, S.; Rush, L.J.; Maharry, K.; Margeson, D.; Davuluri, R.; Wen, J.; Witte, T.; Yu, L.; Liu, C.; Bloomfield, C.D.; Marcucci, G.; Plass, C. \& Caligiuri, M.A. (2008a) DNA hypermethylation and epigenetic silencing of the tumor suppressor gene, SLC5A8, in acute myeloid leukemia with the MLL partial tandem duplication. Blood, Vol. 112, No. 5, (September), pp. 2013-2016, ISSN 0006-4971

Whitman, S.P.; Liu, S.; Vukosavljevic, T.; Rush, L.J.; Yu, L.; Liu, C.; Klisovic, M.I.; Maharry, K.; Guimond; M.; Strout, M.P.; Becknell, B.; Dorrance, A.; Klisovic, R.B.; Plass, C.; Bloomfield, C.D.; Marcucci, G. \& Caligiuri, M.A. (2005) The MLL partial tandem duplication: evidence for recessive gain-of-function in acute myeloid leukemia identifies a novel patient subgroup for molecular-targeted therapy. Blood, Vol. 106, No. 1, (July), pp. 345-352, ISSN 0006-4971

Whitman, S.P.; Maharry, K.; Radmacher, M.D.; Becker, H.; Mrózek, K.; Margeson, D.; Holland, K.B.; Wu, Y.Z.; Schwind, S.; Metzeler, K.H.; Wen, J.; Baer, M.R.; Powell, B.L.; Carter, T.H.; Kolitz, J.E.; Wetzler, M.; Moore, J.O.; Stone, R.M.; Carroll, A.J.; Larson, R.A.; Caligiuri, M.A.; Marcucci, G. \& Bloomfield, C.D. (2010) FLT3 internal tandem duplication associates with adverse outcome and gene- and microRNAexpression signatures in patients 60 years of age or older with primary cytogenetically normal acute myeloid leukemia: a Cancer and Leukemia Group B study. Blood, Vol. 116, No. 18, (November), pp. 3622-3626, ISSN 0006-4971 
Whitman, S.P.; Ruppert, A.S.; Radmacher, M.D.; Mrózek, K.; Paschka, P.; Langer, C.; Baldus, C.D.; Wen, J.; Racke, F.; Powell, B.L.; Kolitz, J.E.; Larson, R.A.; Caligiuri, M.A.; Marcucci, G. \& Bloomfield, C.D. (2008b) FLT3 D835/I836 mutations are associated with poor disease-free survival and a distinct gene-expression signature among younger adults with de novo cytogenetically normal acute myeloid leukemia lacking FLT3 internal tandem duplications. Blood, Vol. 111, No. 3, (February), pp. 1529-1559, ISSN 0006-4971

Wiernik, P. H. (2010) FLT3 Inhibitors for the Treatment of Acute Myeloid Leukemia. Clinical Advances in Hematology and Oncoogy, Vol. 8, No. 6, (June), pp. 429-444, ISSN 15430790

Wittwer, C.T. (2009) High-resolution DNA melting analysis: advancements and limitations. Human Mutation, Vol. 30, No. 6, (June), pp. 857-859, ISSN 1059-7794

Wouters, B.J.; Löwenberg, B. \& Delwel, R. (2009a) A decade of genome-wide gene expression profiling in acute myeloid leukemia: flashback and prospects. Blood, Vol. 113, No. 2, (January), pp. 291-298, ISSN 0006-4971

Wouters, B.J.; Löwenberg, B.; Erpelinck-Verschueren, C.A.; van Putten, W.L.; Valk, P.J. \& Delwel, R. (2009b) Double CEBPA mutations, but not single CEBPA mutations, define a subgroup of acute myeloid leukemia with a distinctive gene expression profile that is uniquely associated with a favorable outcome. Blood, Vol. 113, No. 13, (March), pp. 3088-3091, ISSN 0006-4971

Xiao, J.; Zhang, Z.; Chen, G.G.; Zhang, M.; Ding, Y.; Fu, J.; Li, M. \& Yun J.P. (2009) Nucleophosmin/B23 interacts with p21WAF1/CIP1 and contributes to its stability. Cell Cycle, Vol. 8, No. 6, (March), pp. 889-895, ISSN 1551-4005

Xu, X.; Zhao, Y.; Xu, M.; Dai, Q.; Meng, W.; Yang, J. \& Qin, R. (2010) Activation of Notch signal pathway is associated with a poorer prognosis in acute myeloid leukemia. Medical Oncology, [Epub ahead of print] PMID:20812035, ISSN 1357-0560

Yamamoto, Y.; Kiyoi, H.; Nakano, Y.; Suzuki, R.; Kodera, Y.; Miyawaki, S.; Asou, N.; Kuriyama, K.; Yagasaki, F.; Shimazaki, C.; Akiyama, H.; Saito, K.; Nishimura, M.; Motoji, T.; Shinagawa, K.; Takeshita, A.; Saito, H.; Ueda, R.; Ohno, R. \& Naoe, T. (2001) Activating mutation of D835 within the activation loop of FLT3 in human hematologic malignancies. Blood, Vol. 97, No. 8, (April), pp. 2434-2439, ISSN 00064971

Yang, L.; Han, Y.; Suarez Saiz, F. \& Minden, M.D. (2007) A tumor suppressor and oncogene: the WT1 story. Leukemia, Vol. 21, No. 5, (May), pp. 868-876, ISSN 0887-6924

Ysebaert, L.; Chicanne, G.; Demur, C.; De Toni, F.; Prade-Houdellier N; Ruidavets, J.B.; Mansat-De Mas, V.; Rigal-Huguet, F.; Laurent, G.; Payrastre, B.; Manenti, S. \& Racaud-Sultan, C. (2006) Expression of beta-catenin by acute myeloid leukemia cells predicts enhanced clonogenic capacities and poor prognosis. Leukemia, Vol. 20, No. 7, (July), pp. 1211-1216, ISSN 0887-6924

Yu, Y.; Maggi Jr., L.B.; Brady, S.N.; Apicelli, A.J.; Dai, M.S.; Lu, H. \& Weber, J.D. (2006) Nucleophosmin is essential for ribosomal protein L5 nuclear export. Molecular and Cellular Biology, Vol. 26, No. 10, (May), pp. 3798-3809, ISSN 0270- 7306

Zhang, D.E.; Zhang, P.; Wang, N.D.; Hetherington, C.J.; Darlington, G.J. \& Tenen, D.G. (1997) Absence of granulocyte colony-stimulating factor signaling and neutrophil development in CCAAT enhancer binding protein alpha-deficient mice. The Proceedings of the National Academy of Siences of the USA, Vol. 94, No. 2, (January), pp. 569-574, ISSN 0027-8424 


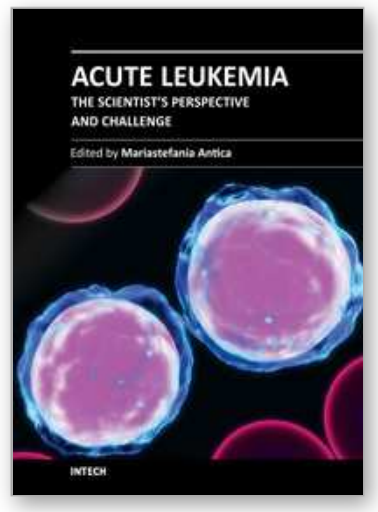

\author{
Acute Leukemia - The Scientist's Perspective and Challenge \\ Edited by Prof. Mariastefania Antica
}

ISBN 978-953-307-553-2

Hard cover, 428 pages

Publisher InTech

Published online 22, December, 2011

Published in print edition December, 2011

This book provides a comprehensive overview of he basic mechanisms underlying areas of acute leukemia, current advances, and future directions in management of this disease. The first section discusses the classification of acute leukemia, taking into account diagnoses dependent on techniques that are essential, and thankfully readily available, in the laboratory. The second section concerns recent advances in molecular biology, markers, receptors, and signaling molecules responsible for disease progression, diagnostics based on biochips and other molecular genetic analysis. These advances provide clinicians with important understanding and improved decision making towards the most suitable therapy for acute leukemia. Biochemical, structural, and genetic studies may bring a new era of epigenetic based drugs along with additional molecular targets that will form the basis for novel treatment strategies. Later in the book, pediatric acute leukemia is covered, emphasizing that children are not small adults when it comes to drug development. The last section is a collection of chapters about treatment, as chemotherapy-induced toxicity is still a significant clinical concern. The present challenge lies in reducing the frequency and seriousness of adverse effects while maintaining efficacy and avoiding over-treatment of patients.

\title{
How to reference
}

In order to correctly reference this scholarly work, feel free to copy and paste the following:

Ota Fuchs (2011). Molecular Markers for Risk Stratification in Adult Acute Myeloid Leukemia with Normal Cytogenetics, Acute Leukemia - The Scientist's Perspective and Challenge, Prof. Mariastefania Antica (Ed.), ISBN: 978-953-307-553-2, InTech, Available from: http://www.intechopen.com/books/acute-leukemia-thescientist-s-perspective-and-challenge/molecular-markers-for-risk-stratification-in-adult-acute-myeloidleukemia-with-normal-cytogenetics

\section{INTECH}

open science | open minds

\author{
InTech Europe \\ University Campus STeP Ri \\ Slavka Krautzeka 83/A \\ 51000 Rijeka, Croatia \\ Phone: +385 (51) 770447 \\ Fax: +385 (51) 686166 \\ www.intechopen.com
}

\author{
InTech China \\ Unit 405, Office Block, Hotel Equatorial Shanghai \\ No.65, Yan An Road (West), Shanghai, 200040, China \\ 中国上海市延安西路65号上海国际贵都大饭店办公楼 405 单元 \\ Phone: +86-21-62489820 \\ Fax: +86-21-62489821
}


(C) 2011 The Author(s). Licensee IntechOpen. This is an open access article distributed under the terms of the Creative Commons Attribution 3.0 License, which permits unrestricted use, distribution, and reproduction in any medium, provided the original work is properly cited. 